\title{
LAST BASTION OF SCHOOL SPONSORED PRAYER? \\ INVOCATIONS AT PUBLIC SCHOOL BOARD MEETINGS: THE CONFLICTING JURISPRUDENCE OF MARSH V. CHAMBERS AND THE SCHOOL PRAYER CASES
}

\author{
BRUCE P. MERENSTEIN $†$
}

\begin{abstract}
And when you pray, be not like the hypocrites, for they love to pray in the synagogues and on the important street corners to be seen by the people.... [W] hen you pray, enter your inner room and with the door closed pray to your Father, the Invisible, and your Father who sees in secret will reward you.
\end{abstract}

[T] he April 8 [school board] meeting opened with the following: "Oh God, dear God, Lord, Jesus Christ, God bless us all, merciful Father."

\section{INTRODUCTION}

One newspaper labeled the practice of opening local government meetings with prayer as "curious." This Comment will not look at how

† B.A. 1985, Brandeis University; M.S. 1988, University of Massachusetts; J.D. Candidate 1998, University of Pennsylvania. For invaluable assistance on this Comment, I would like to thank Professor Pamela Harris and, from the Lazu Review, Nina Abraham, Peter Blumberg, Ryan Pearson, Joelle Polesky and the Associate Editors who put the Comment in working order. I also am indebted to Professors Seth Kreimer and Barbara Woodhouse, who provided me with the proper foundation for thinking through the issues in this Comment. Most importantly, for her unwavering emotional support and for practical assistance without which this Comment never would have seen the light of day, I thank my wife, Karen Stranz. To Karen and to our boys, Alex and Carter, I dedicate this Comment.

Matthew 6:5-:6 (quoting Jesus). For a similar sentiment from a contemporary author, see WilliaM LeE MILleR, PIETY ALONG THE POTOMAC: NOTES ON POLITICS AND MORALS IN THE FIFTIES 46 (1964) ("All religious affirmations are in danger of standing in contradiction to the life that is lived under them, but none more so than these general, inoffensive, and externalized ones which are put together for public purposes.").

Ted Wendling, 2 Board Members Sue over Prayers, PLAIN DEALER (Cleveland), May 22,1996 , at $4 \mathrm{~B}$.

${ }^{9}$ Susan Shelly, Prayer at Board Meetings Not Offensive, Just Curious, READING TIMES, July 29,1987 , at 37 . 
"curious" this practice may be, but at whether it is constitutional. Prayer at public school board meetings, even more so than graduation prayer, ${ }^{5}$ is at the intersection of two distinct and conflicting lines of Supreme Court jurisprudence: the "religion and public schools" arena and the legislative prayer realm."

For almost a half-century, the Supreme Court consistently has held that school-sponsored religious activity, whether sectarian instruction, group prayers or Bible reading, violates the Establishment Clause of the First Amendment. ${ }^{7}$ While there is a common perception that this juris-

${ }^{4}$ This question has yet to be addressed by the Supreme Court or a federal court of appeals. On December 17, 1996, a federal district judge in Ohio rejected the recommendation of a magistrate judge that the Cleveland School Board's practice of beginning its meetings with prayer be found unconstitutional. See Coles v. Cleveland Bd. of Educ., 950 F. Supp. 1337, 1347 (N.D. Ohio 1996) (finding school board prayer constitutional based on the Supreme Court's holding in Marsh v. Chambers, 463 U.S. 783 (1983), that state legislative prayer is constitutional). For the district court's overview of the magistrate's analysis and recommendation, see $i d$. at 1340-41 (noting that the magistrate found that the school board prayer failed the Lemon, coercion and endorsement tests and that she found the Marsh analysis inappropriate in that context). The plaintiffs in Coles are preparing an appeal to the Sixth Circuit Court of Appeals. See Telephone Interview with Joshua R. Cohen, Plaintiff's Counsel, Coles v. Cleveland Bd. of Educ. (Feb. 21, 1997).

No scholarly work has yet analyzed the constitutionality of school board prayer, although attorneys affiliated with the National School Boards Association have concluded that school board prayer is constitutional. See Spencer E. Covert \& Mary E. Binning, Invocations at School Board Meetings: Still Constitutional After All These Years, in RELIGION, EDUCATION AND THE U.S. CONSTrrution 69, 76 (National Sch. Bds. Ass'n ed., 1994); cf. Margaret L. Usdansky, Prayer Ban Lesson for All Schools, ATLANTA J. \& CONST., May 31, 1989, at Al (reporting that, according to Professor John Witte Jr., the legislative prayer case of Marsh v. Chambers "has generally been interpreted to allow prayer before city council meetings .... [b] ut the case did not address school board meetings").

${ }^{5}$ Cf. Gregory M. McAndrew, Note, Invocations at Graduation, 101 YALE L.J. 663, 663 (1991) ("The issue of invocations at public school graduations involves the intersection of two competing strands of Establishment Clause jurisprudence. Graduation prayer is a traditional, ceremonial practice that takes place in the special context of the public schools." (footnote omitted)).

For a thorough discussion of the issue of public prayer, of which legislative prayer is a major subset, see generally Timothy L. Hall, Sacred Solemnity: Civic Prayer, Civil Communion, and the Establishment Clause, 79 IOWA L. REV. 35, 41-93 (1993).

7 The relevant portion of the First Amendment provides, "Congress shall make no law respecting an establishment of religion ...." U.S. CONST. amend. I. The prohibition against government establishment of religion has been made applicable to state and local governments through the Supreme Court's interpretation of the Fourteenth Amendment's Due Process Clause. See Everson v, Board of Educ., 330 U.S. 1, 8 (1947) ("The First Amendment, as made applicable to the states by the Fourteenth ... commands that a state 'shall make no law respecting an establishment of religion, or prohibiting the free exercise thereof....'); Cantwell v. Connecticut, 310 U.S. 296, 303 (1940) ("The Fourteenth Amendment has rendered the legislatures of 
prudence has been based on the "impressionability" of young children, a close examination of the "religion and public schools" cases reveals that, in fact, most of the Court's key cases in this area fail to discuss the issue of "impressionability" at all; the few that do address the issue note simply that the public school context provides a "special" concern, but is not a necessary component of an Establishment Clause violation. ${ }^{9}$

On the other hand, the only time the Court was faced with a challenge to officially sponsored prayer by a government body other than a public school, in Marsh v. Chambers, ${ }^{10}$ it approved the practice. In Marsh, the Court held that Nebraska's "practice of opening [legislative] sessions with prayers by a state-employed clergyman" did not violate the Establishment Clause of the First Amendment. ${ }^{11}$ In so holding, the Court relied primarily on two related justifications. The first justification, which I will refer to as "historical patterns," is that opening legislative sessions with prayer is a longstanding, widely accepted practice that "has coexisted with the principles of disestablishment and religious freedom" for more than two centuries." The second justification, which I will refer to as the "contemporaneous practices" argument, is that the drafters of the Establishment Clause supposedly expressed their support for state legislative prayer by voting to employ a legislative

the states as incompetent as Congress to enact ... laws [respecting an establishment of religion or prohibiting the free exercise thereof]."). The case in which the Court began this consistent line of "religion and public schools" holdings was Illinois ex rel. McCollum v. Board of Education, 333 U.S. 203 (1948), discussed in detail infra Part I.A.1.

${ }^{8}$ See, e.g., Coles, 950 F. Supp. at 1343, 1345-46 (asserting that the Supreme Court has applied stricter scrutiny to Establishment Clause claims in the school setting "due to the impressionability of youth and the compulsory nature of school attendance"); Usdansky, supra note 4, at Al ("The courts have generally held that because of their youth, elementary and secondary school pupils are impressionable and should be protected from institutions like prayer that may be widely accepted by society . . . ."); see also Theresa M. Serra, Note, Invocations and Benedictions-Is the Supreme Count "Graduating" to a Marsh Analysis?, 65 U. DET. L. REV. 769, 785 n.139 (1988) ("The immaturity of young school children and their susceptibility to influence and peer pressure has been a critical factor in several of the Supreme Court's decisions invalidating attempts by the government to introduce religion into the public schools."). Serra provides scant support for her assertion, citing only one Supreme Court majority opinion addressing religion in the public schools. See id. (citing Edwards v. Aguillard, 482 U.S. 578, 584 (1987)).

${ }^{9}$ See, e.g., Wallace v. Jaffree, 472 U.S. $38,61 \mathrm{n} .51$ (1985) (alluding to the fact that government endorsement of religion "has special force in the public-school context"). For a full discussion of this issue, see infra Part I.A.

10463 U.S. 783 (1983).

"Id. at 786.

I2 Id. (noting the presence of legislative prayer "[f]rom colonial times through the founding of the Republic and ever since"). 
chaplain for the first Congress. ${ }^{13}$ Because the Court found it untenable that members of the first Congress "intended the Establishment Clause of the Amendment to forbid what they had just declared acceptable," it held that the practice was constitutional. ${ }^{14}$

These conflicting spheres of Establishment Clause jurisprudence overlap regularly at the public school board meeting. Should officially sponsored prayers at these meetings be governed by the Court's unwavering opposition to religious activity in the public school context? Or are such prayers simply an extension of the "legislative prayer" which the Court approved in Marsh v. Chambers? With a challenge to school board prayer currently being litigated in federal court in Ohio, ${ }^{15}$ it may not be long before the Supreme Court is called upon to resolve this dilemma. ${ }^{16}$

${ }^{13}$ See id. at 788. The United States Congress continues to employ legislative chaplains. See 2 U.S.C. \$ 84-2 (1994) (establishing compensation for House chaplain); id. $\$ 61 d$ (1994) (establishing compensation for Senate chaplain); see also Pete Yost, On Capitol Hill, Many Aides Get High Pay, PHILA. INQUIRER, Oct. 28, 1996, at A7 (noting that the Senate chaplain receives a $\$ 116,000$ salary, while the House chaplain receives $\$ 123,000$ per year).

The Supreme Court has never entertained a challenge to legislative chaplaincies at the federal level. Cf. Murray v. Buchanan, 720 F.2d 689, 690 (D.C. Cir. 1983) (en banc) (per curiam) ("The Supreme Court's decision in Marsh v. Chambers is dispositive of appellants' challenge to the public funding of congressional chaplains."); see also Kurtz v. Baker, 829 F.2d 1133, 1134 (D.C. Cir. 1987) (rejecting, for lack of standing, a challenge to congressional chaplains' refusal to permit plaintiff to offer nontheist invocations), cert. denied, 486 U.S. 1059 (1988). In the Kurtz case, then-Circuit Judge Ruth Bader Ginsburg dissented from the panel's holding that the plaintiff lacked standing. See Kurtz, 829 F.2d at 1145 (Ginsburg, J., dissenting).

${ }_{15}^{14}$ Marsh, 463 U.S. at 790-91.

15 See supra note 4.

${ }^{16}$ It is difficult to determine exactly how prevalent is the practice of prayer at local government meetings, including school board meetings. There are but a few law review articles or books that refer to the practice explicitly. See, e.g., RODNEY K SMITH, PUBLIC PRAYER AND THE CONSTITUTION: A CASE STUdY IN CONSTITUTIONAL INTERPRETATION 237 (1987) (noting that "[p]ublic prayers are offered frequently at the commencement of public meetings at the city and county levels"); Arlin M. Adams \& Charles J. Emmerich, A Heritage of Religious Liberty, 137 U. PA. L. REV. 1559, 1656 (1989) (noting that city "boards and councils often open sessions with invocations").

More common is reference to prayers in newspaper articles. See, e.g., Jeff Nelson, Moment of Silence to Replace Prayer, PHOENIX GAZETTE, Sept. 16, 1992, at IW7 (reporting that only one of twelve school boards in the region began their meetings with prayer); Kelley Root, Area Boards, Councils Pray for Guidance, GRAND RAPIDS PRESS, Mar. 24, 1996, at Al (reporting that one half of school boards in one county open meetings with prayer but only $10 \%$ do so in a neighboring county). These reports and others seem to indicate that the practice, though not widespread, is far from uncommon. In most cases where the practice does exist, it appears to be of fairly recent vintage. See, e.g., Jo Cart, School Board Opens Meeting with Prayer, BATON ROUGE MORNING ADVOc., Feb. 5, 1985 , at $4 \mathrm{~B}$ (reporting "the first opening prayer offered by the board in [the] memory 
This Comment argues that officially sponsored prayers at public school board meetings are unconstitutional. I base this conclusion on a three-part analysis of the issue. Part I will focus on the public school context. First, I will examine the "religion and public schools" cases from the last half-century, demonstrating that any notion that the Court's decisions in this area rest on the impressionability of children cannot withstand scrutiny. Additionally, looking at the purpose and history of the public school and the public school board, I will show that neither the Marsh reasoning nor its holding is applicable to school board prayers. $^{17}$

Part II analyzes the Court's holding in Marsh, questioning whether its exclusive reliance on historical arguments is a useful method of constitutional analysis in the Establishment Clause context, particularly when applied to the setting of public school board meetings. Finally, Part III examines the issue of school board prayer through the Court's primary Establishment Clause tests. Using both reports of school board invocations in practice and the facts of other legislative prayer cases from state and lower federal courts, I will demonstrate the likely purpose and effect of school board prayer, providing the foundation for measuring this conduct against the Court's major Establishment Clause tests. I will conclude this final Part by briefly examining two other pro-

of reporters who have attended meetings for 20 years and more"); Dion Lefler, Prayer at Meetings of School Board Urged, L.A. DAILY NEwS, May 29, 1992, at SVI (noting the proposal to begin opening board meetings with prayer); Dale Moss, A Matter of Principle: School Board May Find Prayer Issue a Hot One, CoURIER-J. (Louisville), Oct. 24, 1990, at 1B (reporting that one school board president eliminated invocations that had been introduced in 1977); Evelyn Theiss, ACLU Opposes School Board Prayers, PLAIN DEALER (Cleveland), July 20, 1992, available in 1992 WL 4285802 (noting the introduction of prayer in January 1992).

Finally, the manner in which prayers are offered seems to vary. See, e.g., Kari Bland, Few Question School Board Using Prajer, ARIZ. REPUBLIC, July 15, 1992, at 61 (noting one district's practice of having district employees and community members give invocations); Manuel Roig-Franzia, Curb on School Prayer Planned, NEW ORLEANS TIMES-PICAYUNE, Aug. 15, 1995, at Al (noting one district's practice of having students lead meeting prayers); Root, supra (reporting that some districts invite ministers to give opening prayers, while others have board members lead the prayers themselves); Wendling, supra note 2 (reporting that prayers are offered by local ministers).

${ }^{17}$ It is worth noting that, prior to 1992 , some courts extended the holding in Marsh to permit prayer at public school graduations. See, e.g., Stein v. Plainwell Community Sch., 822 F.2d 1406, 1409 (6th Cir. 1987) ("The annual graduation exercises here are analogous to the legislative and judicial sessions referred to in Marsh and should be governed by the same principles."). This argument is one that the Supreme Court explicitly rejected in Lee $v$. Weisman, discussed infra Part I.A.3. See Lee v. Weisman, 505 U.S. 577, 597 (1992) (distinguishing Marsh). See generally Serra, supra note 8 (discussing the application of a Marsh-type analysis to the graduation prayer setting). 
posals for reconciling government-sponsored prayer with the Establishment Clause, arguing that neither provides adequate justification for ignoring the Supreme Court's longstanding mandate that "each separate government in this country should stay out of the business of writing or sanctioning official prayers and leave that purely religious function to the people themselves and to those the people choose to look to for religious guidance."

\section{SCHOOL BOARD PRAYER: SETTING THE STAGE}

The fact that the sole Supreme Court legislative prayer case, Marsh v. Chambers, relied exclusively on history-based arguments, ${ }^{19}$ coupled with the short history of the modern public school, ${ }^{20}$ would seem reason enough not to apply the Marsh holding to any issue arising in the context of public schools. However, by ignoring its underlying rationale and interpreting its holding in a broad manner, it might be argued that the Court in Marsh sanctioned all forms of "legislative prayer," no matter how historically and functionally distinct the particular legislative body might be from the Nebraska legislature or the Congress. Therefore, in addition to noting the problems encountered when applying Marsh's questionable reasoning to the public school setting, it is important to review the Court's key "religion and the schools" decisions, in order to lay a foundation for analyzing the constitutionality of prayer at public school board meetings.

It might be argued that the Court's public school decisions are inapplicable to the present issue because the Court was concerned with the coercion of impressionable children who are not present at school board meetings. This argument suffers from at least two flaws. First, in many cases, students do attend school board meetings. ${ }^{22}$ In fact, in some districts where prayer takes place at board meetings, student representatives sit on the school board itself. ${ }^{23}$ For the purposes of this

${ }^{18}$ Engel v. Vitale, 370 U.S. 421,435 (1962) (holding that state officials may not create a state prayer and require schoolchildren to recite it).

${ }_{19}$ See supra notes 12-14 and accompanying text.

20 See infra Part I.B.3.

21 See infra Part II.A.

22 See, e.g., NATIONAL SCH. PUB. RELATIONS ASS'N, THE SCHOOL BOARD MEETING: FACING NEW CHALLENGES FROM THE PUBLIC AND THE MEDIA 27 (1970) (noting that almost half of the districts in a survey reported some student attendance at school board meetings, usually as part of a student assignment); see also Nelson, supra note 16 (reporting that one school board member noted that many school board meetings have students in attendance).

${ }^{23}$ See, e.g., Ernesto Portillo Jr., Prayer at Board Meetings on Way Out, SAN DIEGo 
Comment, however, I will assume, contrary to this evidence, that only adults attend school board meetings.

The more fundamental problem with this argument is that it misreads the Court's school and religion cases. Although some members of the Court have recently advocated a coercion-based test for Establishment Clause violations, ${ }^{24}$ a finding of coercion has been explicitly rejected as a necessary condition for an Establishment Clause violation. ${ }^{25}$ As discussed below, the Court's decisions striking down religious intrusion into public schools have declined to rely exclusively or even primarily on the fact that pupils are young, presumably impressionable, and compelled to attend public schools. Rather, in each of these cases, the Court has focused on the fact that the public school is a governmental institution and one that is particularly important to the maintenance of a democratic, pluralistic society.

\section{A. Religion and Public Schools: From McCollum to Lee}

\section{The Early Years}

For the past fifty years, the Supreme Court's Establishment Clause jurisprudence has been somewhat of a mixed bag. Some religious displays pass constitutional muster; ${ }^{26}$ others do not. ${ }^{27}$ Some funding of religious institutions is met with approval; ${ }^{28}$ some funding is found unconstitutional. $^{2 y}$ However, in the area of public schools, despite

UNION-TRIB., Feb. 24, 1993, available in 1993 WL 7473764 .

${ }^{24}$ See infra Part III.C.

25 See infra notes 57-59 and accompanying text.

${ }^{26}$ See, e.g., County of Allegheny v. ACLU, 492 U.S. 573, 621 (1989) (approving display of Chanukah menorah on government property); Lynch v. Donnelly, 465 U.S. 668,687 (1984) (approving government display of crèche).

${ }^{27}$ See, e.g., Allegheny, 492 U.S. at 601-02 (holding that display of crèche on government property violates the Establishment Clause, but distinguishing the holding from the decision in $L y n c h)$.

${ }^{28}$ See, e.g., Zobrest v. Catalina Foothills Sch. Dist., 509 U.S. 1, 13-14 (1993) (approving state funding of sign language interpreter for deaf student attending religious school); Bowen v. Kendrick, 487 U.S. 589, 593 (1988) (approving participation of religious organizations in government-funded adolescent sex education program); Wolman v. Walter, 433 U.S. 229, 255 (1977) (funding for religious school textbooks, testing and diagnostic services is constitutional).

See, e.g., Wolman, 433 U.S. at 255 (funding for instructional materials and equipment and field trips is not constitutional); Lemon v. Kurtzman, 403 U.S. 602, 625 (1971) (striking down state aid to religious schools in the form of either direct or indirect payment of a portion of teacher salaries). 
criticism from within the Court itself,,$^{30}$ from the other two branches of government, ${ }^{31}$ and from much of the public, ${ }^{32}$ the Court has been remarkably consistent, striking down any state-sponsored religious expression or involvement in the public schools. ${ }^{33}$

The Court first faced the issue of religion and the public schools in two cases decided almost a half-century ago, Mlinois ex rel. McCollum v. Board of Education ${ }^{34}$ and Zorach v. Clauson. ${ }^{35}$ In McCollum, an eight Justice majority (with only Justice Reed dissenting) held that a state program that gave sectarian religious groups access to public school classrooms for religious instruction violated the Establishment Clause. In his opinion for the Court, Justice Black emphasized "the use of taxsupported property for religious instruction and the close cooperation between the school authorities and the religious council in promoting religious education. ${ }^{36}$ In a broad conclusion that appeared to foreclose any commingling between government and religious institutions, the Court held that " $[\mathrm{n}]$ either a state nor the Federal Government can, openly or secretly, participate in the affairs of any religious organiza-

so See generally Lee v. Weisman, 505 U.S. 577, 631-46 (1992) (Scalia, J., dissenting, joined by Rehnquist, C.J., and White and Thomas, JJ.) (criticizing the Court's decision striking down graduation prayer).

${ }^{31}$ See, e.g., President William Clinton, Remarks at James Madison High School on Religious Liberty in America (July 12, 1995) (noting his disagreement with the Supreme Court's decision in Lee $v$. Weisman). For criticism from the legislative branch, see generally Proposed Amendments to the Constitution Relating to Prayers and Bible Reading in the Public Schools: Hearings Before the House Comm. on the Judiciary, 88th Cong. (1964) (debating constitutional amendments that would have allowed prayers in public schools and other public places). Such congressional attempts to overturn Supreme Court decisions addressing religion and the schools have continued unabated for more than 30 years. See, e.g., Prayer in Public Schools and Buildings-Federal Court Jurisdiction: Hearings on S.450 Before the Subcomm. on Courts, Civil Liberties, and the Admin. of Justice of the House Comm. on the Judiciary, 96th Cong. (1980) (debating constitutional amendment that would have the effect of eliminating federal court jurisdiction over cases involving the constitutionality of state laws that regulate school prayer). For the most recent attempts, see S.J. Res. 6, 104th Cong. (1995) (proposing a constitutional amendment that would allow voluntary school prayer) or H.R.J. Res. 16, 104th Cong. (1995) (same). See also 141 CONG. REC. S2151 (daily ed. Feb. 6, 1995) (statement of Sen. Helms) ("[I]n 1962, the Supreme Court forfeited by judicial fiat the rights of millions of American children to invoke in their schools the blessings and guidance of God.").

92 Cf. GEORGE H. GALIUP JR., RELIGION IN AMERICA 1996, at 75 (1996) (noting that $77 \%$ of persons polled in 1974 , and $71 \%$ in 1995 , supported a constitutional amendment allowing prayer in the schools).

\footnotetext{
But cf. infra notes $44-49$ and accompanying text.

333 U.S. 203 (1948).

343 U.S. 306 (1952).

McCollum, 333 U.S. at 209.
} 
tions or groups, and vice versa." ${ }^{37}$ Although the Court has backed away from such a blanket prohibition in recent years, ${ }^{38}$ this statement has been adhered to in the context of public schools in the decades since McCollum.

Justice Frankfurter's concurring opinion in McCollum, joined by three other Justices, concentrated not only on the close relationship between government and religious institutions, but on the unique setting of public schools and the importance of public education. He noted the changing nature of public schools in the United States, from preConstitution times through the framing of the Establishment Clause and the nineteenth and early twentieth centuries. ${ }^{39}$ He then stated a principle that the Court has invoked repeatedly when faced with religious intrusion into public education:

The sharp confinement of the public schools to secular education was a recognition of the need of a democratic society to educate its children, insofar as the State undertook to do so, in an atmosphere free from pressures in a realm in which pressures are most resisted and where conflicts are most easily and most bitterly engendered. Designed to serve as perhaps the most powerful agency for promoting cohesion among a heterogeneous democratic people, the public school must keep scrupulously free from entanglement in the strife of sects. ${ }^{40}$

It is worth remembering these words when returning to the topic at

${ }^{37} I d$. at 210-11. The Court also rejected the argument that the Establishment Clause forbade only "government preference of one religion over another, not an impartial governmental assistance of all religions." Id. at 211.

${ }_{38}$ See, e.g., Bowen v. Kendrick, 487 U.S. 589, 593 (1988) (approving participation of religious organizations in a government-funded sex education program); Marsh $v$. Chambers, 463 U.S. 783, 794-95 (1983) (permitting a Presbyterian minister to participate in opening prayers before the state legislature).

${ }^{39}$ See McCollum, 333 U.S. at 213-20 (Frankfurter, J., concurring). As Justice Frankfurter noted:

The evolution of colonial education, largely in the service of religion, into the public school system of today is the story of changing conceptions regarding the American democratic society, of the functions of State-maintained education in such a society, and of the role therein of the free exercise of religion by the people. The modern public school derived from a philosophy of freedom reflected in the First Amendment.

Id. at 214; see also infra notes $169-71$ und accompanying text.

${ }_{40}$ McCollum, 333 U.S. at 216-17 (Frankfurter, J., concurring). Justice Frankfurter reiterated the point in concluding his opinion:

The public school is at once the symbol of our democracy and the most pervasive means for promoting our common destiny. In no activity of the State is it more vital to keep out divisive forces than in its schools, to avoid confusing, not to say fusing, what the Constitution sought to keep strictly apart.

Id. at 231 . 
hand, invocations at public school board meetings. As Justice Frankfurter recognized, it was not simply "the state's compulsory public school machinery" ${ }^{41}$ that made religious instruction a concern. Rather, it was the unique role of the public school as "perhaps the most powerful agency for promoting cohesion among a heterogeneous democratic people" that required the public school as an institution, not simply as a location where students gathered, to "keep scrupulously free from entanglement in the strife of sects."

Four years after $\mathrm{McCollum}^{43}$ the Court addressed a challenge to a New York City program similar to the program at issue in McCollum. In Zorach $v$. Clauson, ${ }^{44}$ the program at issue allowed pupils the option of being released from secular classroom instruction to be taught religious instruction by nonpublic school teachers. ${ }^{45}$ Unlike the program in McCollum, however, the one in Zorach required participating students to leave the public school premises during the school day and go to religious institutions for religious instruction or prayer services. As Justice Douglas noted, in writing for a six-to-three majority upholding the program, the "'released time' program involves neither religious instruction in public school classrooms nor the expenditure of public funds. ${ }^{\text {"46 }}$ Although the issue in Zorach arguably could be characterized as one involving government funding of religious institutions rather than religious involvement in public schools, ${ }^{47}$ assuming it falls under the latter heading, it represents a rare departure from the Court's strict prohibition against religious involvement in public schools.

Justice Douglas, however, recast the issue in terms of the importance of religious freedom. ${ }^{48}$ He saw no difference between the organ-

4l. Id. at 212 (Black, J.).

${ }^{42}$ Id. at 216-17 (Frankfurter, J., concurring).

${ }^{43}$ In the four years following McCollum the Court's decision striking down "released time" programs within public schools created a great deal of controversy. See Zorach v. Clauson, 343 U.S. 306, 317 (1952) (Black, J., dissenting) (noting that "few opinions from this Court in recent years have attracted more attention or stirred wider debate" than $\mathrm{McCollum}$ ).

343 U.S. 306 (1952).

45 Id. at 308.

${ }^{46}$ Id. at 308-09.

${ }^{47}$ As Justice Douglas noted in response to the contention that the public school system was being used to coerce children into participating in religious instruction, "the school authorities are neutral in this regard and do no more than release students whose parents so request." Id. at 311.

${ }^{48}$ In this vein, Justice Douglas produced arguably the most famous line in Establishment Clause jurisprudence: "We are a religious people whose institutions presuppose a Supreme Being." Id. at 313. It is interesting to note that, although this conclu- 
ized "released time" program and, for example, the request by a Jewish student to be excused from class on Yom Kippur. ${ }^{49}$ The three dissenting Justices, in separate opinions, emphasized the compulsory attendance feature of public schools as providing a benefit to the religious institutions to whom the pupils were released. ${ }^{50}$

A decade would pass before the Court decided another major case involving religion and the public schools. In two cases decided within a year of each other, Engel v. Vitale and School District of Abington Township v. Schempp, ${ }^{52}$ the Court struck down school sponsored prayers and Bible reading in public schools. ${ }^{53}$ Some of the six different majority or concurring opinions in these cases mentioned the concern with combining compulsory school attendance with either prayers or Bible reading. However, it is clear that the constitutional problem with prayer or Bible reading in public schools did not arise from the coercive effect of compulsory attendance or from concern with the malleability of young minds-but rather from the concern with mixing religious activity and

sory dicta has been cited by commentators and Justices countless times since Zorach, Justice Douglas himself later adopted a much broader approach to the Establishment Clause, rejecting any notion that the Constitution permits nonpreferential aid to religion. See, e.g., Walz v. Tax Comm'n of New York, 397 U.S. 664, 716 (1970) (Douglas, J., dissenting) ("If believers are entitled to public financial support, so are nonbelievers.... [O]ne of the mandates of the First Amendment is to promote a viable, pluralistic society and to keep government neutral, not only between sects, but also between believers and nonbelievers.").

${ }^{49}$ See Zorach, 343 U.S. at 313.

${ }_{50}$ Again, this approach makes Zorach appear much more like a government aid to religion case than a religious intrusion in public schools case. See, e.g., id. at 318 (Black, J., dissenting) ("The state thus makes religious sects beneficiaries of its power to compel children to attend secular schools. ... New York is manipulating its compulsory education laws to help religious sects get pupils."); $i d$. at 323 (Frankfurter, J., dissenting) (noting the religious institutions' "attempts to secure public school pupils for sectarian instruction" through the "instrument" of compulsory public school attendance); id. at 323-24 (Jackson, J., dissenting) (arguing that the program is essentially government aid to religion in that the state uses its power to "compel each student to yield a large part of his time for public secular education" and then releases some of the time to him "on condition that he devote it to sectarian religious purposes").

370 U.S. 421 (1962). Justice Black delivered the opinion for the Court in Engel, as he had in McCollum.

32374 U.S. 203 (1963). Schempp was decided along with the companion case of Murray v. Curlett, id.

氵3 In both cases, only Justice Stewart dissented. See Schempp, 374 U.S. at 308 (Stewart, J., dissenting); Engel, 370 U.S. at 444 (Stewart, J., dissenting).

${ }^{34}$ The particular concern that the public schools consisted of a captive audience of impressionable children was briefly mentioned in the concurring opinions of Justice Brennan and Justice Goldberg in Schempp. See Schempp, 374 U.S. at 290-92 \& n.69 (Brennan, J., concurring); id. at 307 (Goldberg, J., concurring). 


\section{a government institution.}

In Engel, a challenge to the group recitation of an official school prayer, both Justice Black's majority opinion and Justice Douglas's concurrence noted a broad concern with a "prayer ... composed by governmental officials as a part of a governmental program to further religious beliefs." ${ }^{35}$ Further, they emphasized the fact that "the person praying is a public official on the public payroll, performing a religious exercise in a governmental institution. ${ }^{56}$ Justice Douglas noted that no evidence existed of coercion of students to participate in the prayers, ${ }^{57}$ but the Court held, "[t]he Establishment Clause, unlike the Free Exercise Clause, does not depend upon any showing of direct governmental compulsion." ${ }^{58}$ Justice Clark, writing for the Court in Schempp, restated this point in noting that "a violation of the Free Exercise Clause is predicated on coercion while the Establishment Clause violation need not be so attended." ${ }^{59}$

Most fundamentally, Engel was about separating an explicitly religious activity ${ }^{60}$ from all governmental institutions. ${ }^{61}$ The fact that young

${ }^{53}$ Engel, 370 U.S. at 425 (Black, J.).

${ }^{56}$ Id. at 441 (Douglas, J., concurring),

${ }^{57} \mathrm{See}$ id. at 438 . Justice Douglas made the same point in his concurrence in Schempp, 374 U.S. at 228 (Douglas, J., concurring) ("In these cases we have no coercive religious exercise aimed at making the students conform."). Indeed, if coercion were the touchstone of an Establishment Clause violation, see infra Part III.C, it is questionable whether the practices at issue in Engel or Schempp would have been struck down.

${ }^{38}$ Engel, 370 U.S. at 430 (Black, J.); see also id. (noting that "[n]either the fact that the prayer may be denominationally neutral nor the fact that its observance on the part of the students is voluntary can serve to free it from the limitations of the Establishment Clause").

${ }_{59}$ Schempp, 374 U.S. at 223.

${ }^{60}$ Notwithstanding later Court decisions allowing some government funding of religious institutions and some government sponsorship of religious displays, as well as Court dicta that phrases such as "In God We Trust" or "One Nation Under God" are harmless, there can be little doubt that "prayer is a religious activity[,] ... a solemn avowal of divine faith and supplication for the blessings of the Almighty." Engeh 370 U.S. at 424. See infra Part III.D.1 for further discussion of this issue.

${ }_{61}$ As Justice Black put it: "It is neither sacrilegious nor antireligious to say that each separate government in this country should stay out of the business of writing or sanctioning official prayers and leave that purely religious function to the people themselves and to those the people choose to look to for religious guidance." Engel, 370 U.S. at 435 (emphasis added). In further attempting to deflect the anticipated criticism that the decision in Engel was antireligious, Justice Black pointed out that the Establishment Clause's "first and most immediate purpose rested on the belief that a union of government and religion tends to destroy government and to degrade religion." Id. at 431 (emphasis added).

Any concerns that the wall of separation erected by McCollum, Engel and Schempp would lead to a decline in religious faith in the United States appear not to have mate- 
pupils' attendance at a public school was compulsory was of little importance in declaring the government-sponsored prayers unconstitutional. ${ }^{62}$ In Schempp as well it was not that the students comprised a captive audience that concerned the eight Justices voting to strike down Bible reading in school, but rather that "the State [was] conducting a religious exercise" and "employ[ing] its facilities or funds in a way that gives any church, or all churches, greater strength in our society than it would have by relying on its members alone."

In these Establishment Clause decisions, from 1948 through 1963, the constitutional problem was the involvement of government in an explicitly religious exercise. To the extent that the public school setting raised extra concern, it was due to the special nature of public schools as "the symbol of our democracy and the most pervasive means for promoting our common destiny," fect of conducting religious activities in a classroom full of children. ${ }^{65}$ This distinction, misunderstood (or purposely obscured) by those who argue for confining the Supreme Court's ban on government prayer to the classroom setting, must be acknowledged before one can undertake a full analysis of the issue of prayer at public school board meetings.

\section{The Middle Years}

In the fifteen years following Schempp, the Court confronted the Establishment Clause most often in the context of government funding of religious institutions. ${ }^{6 /}$ As for religious activities in the public schools

rialized. See, e.g., GALLUP, supra note 32 , at $5-6$ (noting that "the U.S. is one of the most religious nations of the entire industrialized world, in terms of the level of attested religious beliefs and practices" and that the years since World War II "have been the most churched half-century in the nation's history").

${ }_{62}$ The Court noted that the prayer's "observance on the part of the students is voluntary." Engel, 370 U.S. at 430. Rather than dispute this allegation factually, based on compulsory attendance laws, the Court simply noted that this point was irrelevant to the constitutionality of the prayer. See id.

${ }^{63}$ Schempp, 374 U.S. at 229 (Douglas, J., concurring). Justice Brennan, in concurrence, echoed Justice Frankfurter's sentiments in McCollum. See Illinois ex rel. McCollum v. Board of Educ., 333 U.S. 203, 231 (1948) (Frankfurter, J., concurring) ("The public school is at once the symbol of our democracy and the most pervasive means for promoting our common destiny."); see also Schempp, 374 U.S. at 230 (Brennan, J., concurring) ("Americans regard the public schools as a most vital civic institution for the preservation of a democratic system of government.").

G McCollum, 333 U.S. at 231 (Frankfurter, J., concurring).

${ }^{65}$ See supra text accompanying notes 58-59 (noting that violation of the Establishment Clause is not predicated on a finding of coercion).

${ }^{66}$ See, e.g., Wolman v. Walter, 433 U.S. 229, 232, 255 (1977) (upholding some categories of state funding to parochial schools and striking down others); Tilton v. Rich- 
themselves, the only major case, Epperson v. Arkansas, ${ }^{67}$ involved an un-

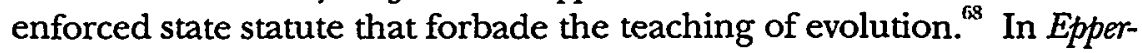
son, the Court invalidated the statute solely due to its purpose of advancing religious beliefs. ${ }^{\text {"s }}$

In the 1980s, however, at least three cases would give the Court the opportunity to revisit the relationship between religion and the public schools under the Establishment Clause. In the first of these, Stone $v$. Graham, ${ }^{70}$ the Court invalidated the posting of the Ten Commandments in Kentucky public schools, finding that the "pre-eminent purpose for posting the Ten Commandments on schoolroom walls [was] plainly religious in nature." Again, the Court had no need to analyze the effect of the challenged practice on children, striking down the statute in question solely based on its clearly religious purpose.

Next, in Wallace v. Jaffree, ${ }^{73}$ the Court revisited the school prayer issue, albeit in the guise of an Alabama statute providing for "a period of silence... for meditation or voluntary prayer." ${ }^{74}$ As in Epperson and Graham, the Court invalidated the statute in question because it lacked a secular purpose. ${ }^{75}$ Although the Court noted that the complaint "alleged that two of the children had been subjected to various acts of

ardson, 403 U.S. 672, 673-74, 689 (1971) (upholding federal assistance to churchrelated institutions of higher learning); Lemon v. Kurtzman, 403 U.S. 602, 606-07 (1971) (finding unconstitutional state programs supplementing parochial school teacher salaries); Walz v. Tax Comm'n of New York, 397 U.S. 664, 666-69, 680 (1970) (upholding property tax exemptions granted to religious organizations); Board of Educ. v. Allen, 392 U.S. 236, 238 (1968) (upholding law authorizing public schools to lend textbooks free of charge to parochial school students).

${ }^{67} 393$ U.S. 97 (1968).

Gee id. at 98 .

69 As the Court noted, "[n]o suggestion has been made that Arkansas' law may be justified by considerations of state policy other than the religious views of some of its citizens. It is clear that fundamentalist sectarian conviction was and is the law's reason for existence." Id. at 107-08 (footnote omitted). In other words, the effect on young children of the particular curricular requirement was not relevant; the religious purpose of the law made it unconstitutional.

70 U.S. 39 (1980) (per curiam).

${ }^{7} I d$. at 41 . To those who might argue that the posting of the Ten Commandments was a matter unworthy of the Court's attention, the Court responded that "it is no defense to urge that the religious practices here may be relatively minor encroachments on the First Amendment."' Id. at 42 (quoting School Dist. of Abington Township v. Schempp, 374 U.S. 203, 225 (1963)).

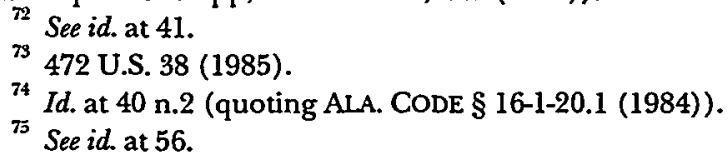


religious indoctrination, ${ }^{76}$ it found no need to rely on this contention in its analysis of the statute. Rather, it indicated that in past cases "the Court has unambiguously concluded that the individual freedom of conscience protected by the First Amendment embraces the right to select any religious faith or none at all." ${ }^{27}$ Therefore, a statute whose purpose was to encourage the expression of religious faith in general was constitutionally suspect. ${ }^{78}$ In concurring opinions, both Justice Powell and Justice O'Connor found the statute unconstitutional without relying on any coercion present in the classroom context. ${ }^{79}$

The final major "religion and public schools" case before the present decade was Edwards v. Aguillard, ${ }^{80}$ another challenge to a religiously based curriculum regulation. ${ }^{81}$ In Justice Brennan's majority opinion, the Court for the first time appeared as if it would concentrate on (rather than ignore or cite in dicta) "the particular concerns that arise in the context of public elementary and secondary schools." ${ }^{32}$ The

${ }^{76} I d$. at 42.

77 Id. at 52-53.

${ }^{78}$ See id. at 56-60 \& nn.43-44 (noting that the legislative history and testimony by the statute's sponsor revealed the "wholly religious character" of the statute). The Court did indicate, in a single footnote at the end of its 22-page opinion, that concern regarding government endorsement of religious activity "has special force in the public-school context where attendance is mandatory." Id. at $61 \mathrm{n} .51$.

${ }^{79}$ Justice Powell specifically distinguished prayer in Wallace from the prayer in Marsh, based on "the historical acceptance of the practice" in question in Marsh, not based on the different audiences in the two cases. Id. at 63 \& n.4 (Powell, J., concurring). Justice O'Connor noted that the earlier school prayer cases had "acknowledged the coercion implicit under the statutory schemes, but they expressly turned only on the fact that the government was sponsoring a manifestly religious exercise." Id. at 72 (O'Connor, J., concurring in judgment) (emphasis added) (citation omitted).

Justice O'Connor also noted that the historical arguments from Marsh were inapplicable in the school context, not because there were adults at issue in Marsh and children in Wallace, but because:

The simple truth is that free public education was virtually nonexistent in the late 18th century. Since there then existed few government-run schools, it is unlikely that the persons who drafted the First Amendment, or the state legislators who ratified it, anticipated the problems of interaction of church and state in the public schools. Even at the time of adoption of the Fourteenth Amendment, education in Southern States was still primarily in private hands, and the movement toward free public schools supported by general taxation had not taken hold.

Id. at 80 (citations omitted).

482 U.S. 578 (1987).

${ }^{81}$ See id. at 580-81. Here, the Court addressed a challenge to a Louisiana curriculum regulation that required that any teaching of evolution be accompanied by the teaching of "creation science." Id. at 581.

${ }^{82}$ Id. at 585 . 
Court's opinion began by noting both that "[s] tudents in such institutions are impressionable ${ }^{\$ 83}$ and that, as Justice Frankfurter explained in his $\mathrm{McC}$ Collum opinion, public schools are the most important tool for "'promoting our common destiny." ${ }^{84}$ However, the Court's holding did not rely on the special circumstances of the school setting but, as in Wallace, found the statute unconstitutional because its legislative context indicated "the legislature's preeminent religious purpose in enacting th $[\mathrm{e}]$ statute. ${ }^{\prime \prime 5}$ In fact, the Court spent more time expressing concern for the effect of the religiously motivated statute on adult teachers than on young pupils. ${ }^{86}$

As the handful of cases from the three decades following Schempp clearly indicate, the Court continued to analyze challenges to religious exercises in public schools under the broad Establishment Clause principle of separating religious exercises and government institutionsand not under a coercion analysis grounded in concern for the impressionability of young children. In fact, from 1948 through the 1980s, without exception, the Court found unconstitutional every incursion of religion into the public schools, based on the requirement that government refrain from engaging in any religious activity and, in some cases, on the importance of the public school institution as a symbol of democracy and pluralism. It was against this background that the Court considered the practice of official prayers at public school graduation ceremonies in the 1992 case of Lee $v$. Weisman. ${ }^{87}$

${ }^{83}$ Id. at 584 .

${ }^{84}$ Id. (quoting Illinois ex rel. McCollum v. Board of Educ., 333 U.S. 203, 231 (1948) (Frankfurter, J., concurring)).

${ }^{85}$ Id. at 590 (emphasis added). In a concurring opinion, Justice Powell agreed with the majority that the legislature "acted with the unconstitutional purpose of structuring the public school curriculum to make it compatible with a particular religious belief: the "divine creation of man."' Id. at 604 (Powell, J., concurring). As with the majority, Justice Powell's concern was not with the effect on pupils, but with the government's "purpose of promoting a particular religious belief." Id.

${ }^{86}$ See, e.g., id. at 586 n. 6 (majority opinion) ("The Act actually serves to diminish academic freedom by removing the flexibility to teach evolution without also teaching creation science, even if teachers determine that such curriculum results in less effective and comprehensive science instruction."); id. at 588-89 ("[U]nder the Act's requirements, teachers who were once free to teach any and all facets of [scientific theories about the origins of humankind] are now unable to do so.").

Finally, as in Justice O'Connor's opinion in Wallace, the Court explicitly rejected applying Marsh in the public school setting, as "a historical approach is not useful in determining the proper roles of church and state in public schools, since free public education was virtually nonexistent at the time the Constitution was adopted." Id. at 583 n. 4.

${ }^{87} 505$ U.S. 577 (1992). 


\section{The Later Years}

It is worth noting, when considering whether the Court would.apply Marsh to the practice of public school board prayer, that some courts and commentators believed that the Court would (or should) apply Marsh to the issue of graduation prayer-thereby finding it constitutionally permissible. ${ }^{88}$ However, this was not to be the case. Justice Kennedy's majority opinion in Lee explicitly stated the "dominant facts" that led to the Court's holding: "State officials direct the performance of a formal religious exercise at promotional and graduation ceremonies for secondary schools. ${ }^{89}$ Justice Kennedy considered attendance at the ceremonies "obligatory," not in the sense that a concrete detriment (such as failure to receive a diploma) would befall absentees, but in terms of the "intangible benefits" that would be lost by a student who felt compelled to absent herself from the graduation ceremony. ${ }^{90}$ Justice Kennedy found that the "government involvement with religious activity" in Lee was "pervasive." "91 Most fundamentally, he declared that the activity challenged in Lee violated the most basic precepts of the First Amendment religion clauses:

The First Amendment's Religion Clauses mean that religious beliefs and religious expression are too precious to be either proscribed or prescribed by the State. The design of the Constitution is that preservation and transmission of religious beliefs and worship is a responsibility and a choice committed to the private sphere, which itself is promised freedom to pursue that mission.

It was only at this point, after establishing that the underlying problem in this case was government involvement in the "transmission of religious beliefs and worship,"

${ }^{88}$ See, e.g., Stein v. Plainwell Community Sch., 822 F.2d 1406, 1409 (6th Cir. 1987) ("The annual graduation exercises here are analogous to the legislative and judicial sessions referred to in Marsh and should be governed by the same principles."); Serra, supra note 8, at 796-98 (suggesting that Marsh and its progeny would lead the Court to uphold graduation prayer).

${ }^{89}$ Lee, 505 U.S. at 586.

90 Id. at 586, 595. Importantly, and surprisingly to many Court observers, Justice Kennedy declined "the invitation of petitioners and amicus the United States to reconsider" the Lemon test, id. at 587, the Court's major Establishment Clause test, discussed infra Part III.A.

${ }_{91}$ Lee, 505 U.S. at 587 . Justice Kennedy based his conclusion on the fact that "from a constitutional perspective it is as if a state statute decreed that the prayers must occur," id., and the fact that the government official "directed and controlled the content of the prayers, ${ }^{\prime} i d$. at 588.

${ }_{92}$ Id. at 589. 
"concerns have particular application in the case of school officials, whose effort to monitor prayer will be perceived by the students as inducing a participation they might otherwise reject. ${ }^{\text {"94 }}$

It is Justice Kennedy's analysis of the "particular application" of the basic First Amendment principles in the context of an audience of adolescents ${ }^{95}$ that received the most attention-and to which Justice Scalia's dissent most directly responded. ${ }^{96}$ Although four Justices joined Justice Kennedy's opinion, they all either wrote or joined concurring opinions as well. Justice Blackmun, joined by Justices Stevens and O'Connor, failed to discuss the special issue of children and religion altogether, instead reviewing the Court's long line of Establishment Clause cases. ${ }^{97}$ He concluded by noting that "our cases have prohibited government endorsement of religion, its sponsorship, and active involvement in religion, whether or not citizens were coerced to conform."

${ }^{94} I d$. at 590.

${ }^{95}$ See id. at 592-97. In his analysis of the public school context, Justice Kennedy overstated the importance of this setting in the opinions in Engel and Schempp when he noted that these cases "recognize, among other things, that prayer exercises in public schools carry a particular risk of indirect coercion." Id. at 592. For a discussion of Engel and Schempp, see supra notes 51-63 and accompanying text. On the other hand, even while discussing the particular problem of official religious exercises and young people, Justice Kennedy reiterated the fundamental problem with state-sponsored prayer, a problem inherent in any context: "It is a tenet of the First Amendment that the State cannot require one of its citizens to forfeit his or her rights and benefits as the price of resisting conformance to state-sponsored religious practice." Lee, 505 U.S. at 596 .

${ }^{96}$ See Lee, 505 U.S. at 636-44 (Scalia, J., dissenting) ("The Court's argument that state officials have 'coerced' students to take part in the invocation and benediction at graduation ceremonies is, not to put too fine a point on it, incoherent."). As discussed below, four of the Justices in the majority found no need to rely on a "psychological coercion" argument to create a stricter Establishment Clause standard when children were involved. See infra notes 97-101 and accompanying text. Even Justice Kennedy placed heavier reliance on general Establishment Clause principles than on any "particular concerns" with the graduation context. See supra notes $89-93$ and accompanying text. Nevertheless, Justice Scalia, joined by Chief Justice Rehnquist and Justices White and Thomas, took issue primarily with the majority's supposed reliance on a "boundless, and boundlessly manipulable, test of psychological coercion." Lee, 505 U.S. at 632 (Scalia, J., dissenting). The dissenters would have upheld the graduation prayer as "a tradition that is as old as public school graduation ceremonies themselves, and that is a component of an even more longstanding American tradition of nonsectarian prayer to God at public celebrations generally." Id. Analysis of the longstanding historical practices argument can be found infra Part II.A.1, while the history of public schools is discussed infra Part I.B.3, and the notion of "nonsectarian prayer" is analyzed infra Part III.D.1.

${ }_{97}$ See Lee, 505 U.S. at 599-609 (Blackmun, J., concurring).

98 Id. at 609. 
Justice Souter, also joined by Justices Stevens and O'Connor, addressed primarily two issues: whether the Establishment Clause was intended to permit government endorsement of, and involvement in, religious exercises in a nonpreferential manner ${ }^{\text {g9 }}$ and whether an Establishment Clause violation necessarily required an element of coercion. ${ }^{100}$ His opinion, like Justice Blackmun's and like the first portion of Justice Kennedy's, focused on actions by any government entity that "favor or endorse either religion generally over nonreligion or one religion over others," and not on the particular concerns of the young public school audience. ${ }^{101}$ In the five years since Lee, the Supreme Court has not had an opportunity to revisit the issue of religious involvement in public schools. ${ }^{102}$

\section{B. Public Schools and School Boards}

The preceding Section demonstrates at least two overriding principles behind the Court's series of "religion and public schools" cases. First and foremost, the Court has unalterably rejected any religious exercise in the public school context. The second portion of Justice Kennedy's opinion in Lee notwithstanding, the basis for this rejection has not been concern for the undue influence on young minds, but has been the Establishment Clause tenet of neutrality that requires a sepa-

${ }^{99}$ See id. at 609-618 (Souter, J., concurring).

${ }^{100}$ See id. at 618-626. Justice Souter's opinion relied heavily on the history of the Establishment Clause. Ultimately, he rejected the coercion test because he found no support for such a narrow reading of the Establishment Clause in either the history of its framing or the Court's long line of precedents, and because "a literal application of the coercion test would render the Establishment Clause a virtual nullity," as it would prohibit only government actions already forbidden under the Free Exercise Clause. Id. at 621; cf. Tr. of Oral Argument at 18, Lee (No. 90-1014) (Justice: "Do you have to have the same level of coercion to satisfy ... an establishment challenge, as you do a free exercise challenge?" Charles J. Cooper, counsel for respondent: "Your Honor, I cannot think of an instance where that might not be the case.").

${ }_{101}$ See Lee, 505 U.S. at 627 (Souter, J., concurring).

${ }^{102}$ The Court has decided a few Establishment Clause cases dealing with the public schools since Lee v. Weisman, but I would characterize these cases as either funding or accommodation cases in which the Court did not address the fundamental issue in the cases discussed above, the participation of government in a religious exercise. See, e.g., Board of Educ. of Kirays Joel Village Sch. Dist. v. Grumet, 512 U.S. 687, 710 (1994) (finding that the creation of a school district to serve the cultural needs of a particular religious sect "crosse[d] the line from permissible accommodation to impermissible establishment"); Zobrest v. Catalina Foothills Sch, Dist., 509 U.S. 1, 13-14 (1993) (finding that "the Establishment Clause does not prevent [a public] school district from furnishing [a pupil in a sectarian school] with a sign-language interpreter in order to facilitate his education"). 
ration between religious exercises and government authority. Second, the Court has emphasized the importance of public schools in general (and not simply the public classroom as a physical entity) as perhaps the essential ingredient in our modern democratic and pluralistic society. These principles inform the discussion below, which will distinguish the setting of public school board meetings from that of the state legislatures at issue in Marsh.

\section{The Role of the Public School}

The Supreme Court occasionally has discussed the importance of public schools in contexts other than Establishment Clause challenges. In West Virginia Board of Education v. Barnette, ${ }^{103}$ the Supreme Court noted both the central role of the Bill of Rights in protecting minority views from majority persecution ${ }^{104}$ and the importance of public schools in our modern democratic society:

Free public education, if faithful to the ideal of secular instruction and political neutrality, will not be partisan or enemy of any class, creed, party, or faction....

... That [school boards] are educating the young for citizenship is reason for scrupulous protection of Constitutional freedoms of the individual, if we are not to strangle the free mind at its source and teach youth to discount important principles of our government as mere platitudes.

${ }^{103} 319$ U.S. 624 (1943) (finding unconstitutional a statute that mandated saluting the flag and reciting the pledge of allegiance).

104 In Justice Jackson's famous words:

The very purpose of a Bill of Rights was to withdraw certain subjects from the vicissitudes of political controversy, to place them beyond the reach of majorities and officials and to establish them as legal principles to be applied by the courts. One's right to life, liberty, and property, to free speech, a free press, freedom of worship and assembly, and other fundamental rights may not be submitted to vote; they depend on the outcome of no elections.

$I d$. at 638. Strict adherence to the Court's view in Barnette would seem to preclude any government prayers or religious expression justified as simply "beliefs widely held among the people." Marsh v. Chambers, 463 U.S. 783, 792 (1983). But cf. Employment Div., Dep't of Human Resources v. Smith, 494 U.S. 872, 890 (1990) ("Values that are protected against government interference through enshrinement in the Bill of Rights are not thereby banished from the political process."); County of Allegheny v. ACLU, 492 U.S. 573, 679 (1989) (opinion of Kennedy, J.) (arguing that communities should be able to make "reasonable judgments" regarding which acknowledgments of sectarian religious holidays are appropriate).

${ }^{105}$ Bamette, 319 U.S. at 637. 
In addition to the "secular instruction and political neutrality" that the Barmette Court urged on public schools, the Court unanimously stated four decades ago that "education is perhaps the most important function of state and local governments" and is critical "to our democratic society." ${ }^{106}$ Finally, the Court has noted the widespread agreement that "public schools [are] an 'assimilative force' by which diverse and conflicting elements in our society are brought together on a broad but common ground" and are places where "fundamental values necessary to the maintenance of a democratic political system" are inculcated. ${ }^{107}$

The school board's role in fulfilling the above functions "is not confined to books, the curriculum, and the civics class; schools must teach by example the shared values of a civilized social order." ${ }^{108}$ It is highly questionable whether the values cited above of secular instruction, political neutrality, democracy and diversity will be taught by the example of a school board sponsoring "a religious exercise in a governmental institution." 109 In fact, some people believe that a strong argument in favor of school board prayer is precisely the example that will be set for students. ${ }^{110}$ Not surprisingly, some students have received the message from prayers at school board meetings that they should also be able to pray in school. ${ }^{\text {II }}$

${ }^{106}$ Brown v. Board of Educ., 347 U.S. 483, 493 (1954).

${ }^{107}$ Ambach v. Norwick, 441 U.S. 68, 77 (1979) (upholding against an equal protection challenge a New York statute forbidding permanent certification as a public school teacher of any person who is not a United States citizen). Members of the Court have expressed similar views regarding the role of schools in many other cases. For example, in his dissenting opinion in Board of Education v. Pico, 457 U.S. 853 (1982), Justice Rehnquist noted the fundamental role of public schools "in inculcating social values and knowledge in relatively impressionable young people." Id. at 909 (Rehnquist, J., dissenting); see also Rendell-Baker v. Kohn, 457 U.S. 830, 848 (1982) (Marshall, J., dissenting) ("The provision of education is one of the most important tasks performed by government: it ranks at the very apex of the function of a State.").

${ }^{108}$ Bethel Sch. Dist. No. 403 v. Fraser, 478 U.S. 675, 683 (1986) (emphasis added); cf. E. EDMUND REUTTER, JR, LEGAL ASPECTS OF CONTROL OF STUDENT ACTIVITIES BY PUBLIC SCHOOL AUTHORITIES 53 (1970) ("How school personnel react to the challenge to their authority is ... important not only for the function of the schools but for the development of youths' general attitudes toward their government.").

${ }^{109}$ Engel v. Vitale, 370 U.S. 421, 441 (1962) (Douglas, J., concurring) (discussing the official prayer that the state of New York required to be recited at the beginning of each school day).

${ }^{110}$ See, e.g., Betty Szubo, Letter, Praying Silently, ARIz. REPUBLIC, Oct. 17, 1992, at All (noting that "since [board members] were the people who made policy for the schools in the district, they could set an example for the students by starting their meetings with a prayer"); Nelson, supra note 16 (reporting that a school board member voted to retain meeting prayers "because the board acts as a model for district students").

${ }^{111}$ Cf. Students to Carry Ball on Graduation Prayer, SALT LAKE TRIB., Mar. 30, 1991, at 
Given that the "public schools... are expected to take the lead in helping to create a society without prejudice and to promote the full equality of all citizens," setting is problematic. In fact, as one scholar noted: "[T]here is no place in American life where the Establishment Clause should be more clearly manifest than in America's public schools.... [T] he public schools have a solemn obligation not only to teach the Constitution, but also to uphold it by precept and practice. ${ }^{\text {,113 }}$

\section{School Board Meetings vs. Legislative Sessions}

As an initial matter in examining the public school board meeting, it is important to understand the procedural posture of cases such as Engel and Schempp. In those cases, although particular school districts were targeted as defendants, state statutes that granted the schools authority to initiate the prayers or Bible reading were the ultimate target of the legal challenges. ${ }^{114}$ In the case of school board prayer, it is unlikely that explicit statutory authority exists for such prayers, as the role and authority of public school boards is one of limited scope, defined by state legislation that typically delegates authority to run local schools to elected (or occasionally appointed) officials in local communities. ${ }^{115}$ This limited authority of public school boards not only raises the question of whether they have the power (let alone the constitu-

C8 (reporting that a student "wanted to know why students can't have prayer at graduation but the school board commonly has prayer at the beginning of each of its meetings").

112 James R. Kirkpatrick, Public Schools and the American Heritage of Religious Freedom and Religious Pluralism, in RELIGION, THE STATE, AND EDUCATION 111, 113 (James E. Wood, Jr. ed., 1984); see also WARREN A. NORD, RELIGION AND AMERICAN EDUCATION 374 (1995) ("[P]ublic schools have a particularly important role to play in nurturing a sense of community, respect, and mutual understanding in a pluralistic and increasingly fragmented culture."); Paul $\mathrm{H}$. Hirst, Public and Private Values and Religiones Educational Content, in RELIGION AND PUBLIC EDUCATION 329, 329 (Theodore R. Sizer ed., 1967) ("To anyone who cares about religious freedom and toleration, the American public school is a magnificent attempt at maintaining the strictest religious neutrality by the state while providing the best possible education for all.").

${ }^{113}$ James E. Wood, Jr., Religion and Education: A Continuing Dilemma, ANNALS AM. ACAD. POL. \& SOC. SCI., Nov. 1979, at 63, 70.

${ }^{114}$ See School Dist. of Abington Township v. Schempp, 374 U.S. 203, 205, 211 (1963) (citing state statutes that required reading from the Bible at the opening of each school day); Engel v. Vitale, 370 U.S. 421, 423 \& n.I (1962) (noting that the board of education acted under state law in directing the principal to cause a prayer to be recited aloud each day in class).

${ }^{115}$ See, e.g., PA. STAT. ANN. tit. 24, $§ \S 5-508,5-510$ (West 1992) (discussing the duties and powers of Pennsylvania school boards). 
tional right) to conduct prayer exercises at their official meetings, but also serves as a foundation on which to examine the differences between state legislatures and local school boards.

The strictly limited authority of school boards is unlike that of state and federal legislatures, which have wide-ranging powers over large numbers of constituents. ${ }^{116}$ In addition, Congress is a coequal branch of government to which the federal courts give great deference ${ }^{117}$ and federalism concerns likewise restrict these courts from interfering with the state legislative process. ${ }^{118}$ School boards, however, present no such problems. ${ }^{19}$ Although the Court has expressed concern about becoming too intimately involved in curricular decisions of school districts, ${ }^{120}$

116 See, e.g., U.S. CONST. art. I, \$8 (listing powers of Congress); Blackwell v. State Ethics Comm'n, 567 A.2d 630, 636 (Pa. 1989) (interpreting Article 2, § 1, of the Pennsylvania Constitution as vesting broad "power to make, alter, and repeal laws" in the state legislature (internal quotations omitted)), affd on reh'g, 589 A.2d 1094 (Pa. 1991).

117 See Schweiker v. Chilicky, 487 U.S. 412, 423 (1988) (applying "appropriate judicial deference" to Congress when determining whether to create an implied cause of action for an alleged constitutional violation). Unlike school districts' authority, Congress's power to regulate its internal affairs is constitutionally based. See, e.g., U.S. CONST. art. I, $\S 5, \mathrm{cl}$. 1 ("Each House shall be the Judge of the Elections, Returns and Qualifications of its own Members ...."); id. §5, cl. 2 ("Each House may determine the Rules of its Proceedings ...."); id. $\$ 6, \mathrm{cl} .1$ ("[F]or any Speech or Debate in either House, [Senators and Representatives] shall not be questioned in any other Place.").

${ }^{118}$ See, e.g., Tenney v. Brandhove, 341 U.S. 367, 376 (1951) (affirming state legislators' broad immunity from federal civil rights actions); $c f$. Younger v. Harris, 401 U.S. 37,44 (1971) (citing comity, or "a proper respect for state functions," as justification for federal court deference to state criminal proceedings). The Court has interpreted the Eleventh Amendment broadly to provide virtually unlimited immunity for states, but has explicitly refused to extend this immunity to school districts, finding the principle of "sovereignty" underlying the Eleventh Amendment inapplicable in the case of school districts. See U.S. CoNST. amend. XI. Compare, e.g., Seminole Tribe v. Florida, 116 S. Ct. 1114, 1122 (1996) (limiting congressional power to subject States to federal court jurisdiction), with Mt. Healthy City Sch. Dist. Bd. of Educ. v. Doyle, 429 U.S. 274, 280-81 (1977) (declining to extend Eleventh Amendment immunity to school districts).

See, e.g., Sands v. Morongo Unified Sch. Dist., 809 P.2d 809, 819 n.9 (Cal. 1991) (en banc) (noting that Marsh is properly understood as deriving in part from the judiciary's deference to the legislative branch in the management of that branch's own internal affairs," a deference "not implicated" in the case of graduation prayer); $c f$. Voswinkel v. City of Charlotte, 495 F. Supp. 588, 597 (W.D.N.C. 1980) (declining to apply the "historic reluctance of the courts to interfere in the internal affairs of legislative bodies" to a challenge to a police department chaplaincy); James J. Dean, Comment, Ceremonial Invocations at Public High School Events and the Establishment Clause, 16 FLA. ST. U. L. REV. 1001, 1013 (1989) (noting that invocations at school events do "not implicate the deference traditionally accorded another branch of government in the internal ordering of its own affairs").

${ }^{120}$ See, e.g., Board of Educ. v. Pico, 457 U.S. 853, 882 (1982) (Blackmun, J., concurring) ("As the Court has recognized, school officials must have the authority to make 
it has not hesitated to impose constitutional constraints on school districts when necessary. ${ }^{121}$

In the everyday sense as well, the "internal affairs" of a school board are quite different from those of a state or federal legislature. Once state or federal legislators are elected, they typically fulfill their official roles by traveling to their capital cities and taking care of their business, with most of their constituents residing far from the locus of legislative action (and legislative prayer). ${ }^{122}$ Because school boards usually cover fairly small geographic areas and their meetings provide constituents an intimate opportunity to comment on a narrow range of issues (for example, local taxes, educational programs, building projects), citizen attendance is more common, more expected and more visible:

The board of education meeting, which takes place all across the land

educationally appropriate choices in designing a curriculum ....").

${ }^{121}$ Probably the most prominent example is the long line of school desegregation cases, beginning with the remedial phase of Brown v. Board of Education, 349 U.S. 294 (1955) (ordering the district courts to take proceedings necessary to desegregate the public schools with "all deliberate speed"). See also, e.g., Milliken v. Bradley, 433 U.S. 267 (1977) (holding that a district court could order remedial education programs for schoolchildren who have been subjected to past acts of de jure segregation). Although the Court has recently cut back on federal courts' authority to intervene in public schools in order to effectuate desegregation, the principle underlying this change is deference to states, not to the public schools themselves. See, e.g., Missouri v. Jenkins, 115 S. Ct. 2038, 2054 (1995) (invalidating portions of district court desegregation remedy - which were supported by the school district itself - while noting the "federalism concerns that are implicated when a federal court issues a remedial order against a State").

In addition, in other areas, the Court has clearly distinguished between the deference due state legislators and that due local school board members. See, e.g., Wood v. Strickland, 420 U.S. 308, 322 (1975) (declining to grant school board members the same immunity from damages in federal civil rights actions that was granted to state legislators in Tenney v. Brandhove, 341 U.S. 367 (1951)).

${ }^{122}$ Cf. Jacqueline P. Danzberger \& Michael D. Usdan, Strengthening a Grass Roots American Institution: The School Board, in SCHOOL BOARDS: CHANGING LOCAL CONTROL 91, 92 (Patricia F. First \& Herbert J. Walberg eds., 1992) (noting increasing centralization of government decisionmaking with the exception of school boards, which "are one of the last bastions of meaningful local government"). Although Danzberger and Usdan celebrate the fact that school board officials usually "are representing the values of their local constituents," id. at 93, James Madison was concerned about the lack of amultiplicity of sects" at the local level, making it more likely at the local level than at the national level that an elected majority would involve itself, through government, in religious matters. See LYNDA BECK FENWICK, SHOULD THE CHILDREN PRAY? A HISTORICAL, JUDICIAL, AND POLITICAL EXAMINATION OF PUBLIC SCHOOL PRAYER 101-03 (1989) (discussing Madison's concern in this regard). But of. 130 CONG. REC. 5,917 (1984) (statement of Sen. Hatch) (deflecting concern about the content of school prayer if a constitutional amendment were passed because "the decision would be up to countless local officials and school administrators across the country"). 
-and on a regular basis-is one of democracy's last assembly places where any citizen, by the simple virtue of being a taxpayer, student, parent, or employee, can feel rightfully, even wrathfully, able to assert his full authority to observe or even speak....

One who objects to the Nebraska legislative prayer is not likely to be noticed and commented upon; a local community member who stands up and walks out of the school board meeting may not retain such anonymity.

The proper role of the modern school system ${ }^{124}$ and the community involvement unique to public schools come together most prominently at the regular school board meeting: "It is at the school-board meeting that members discharge their responsibilities for public education in the district. The school-board meeting is, therefore, of great significance to the administration of public education." ${ }^{125}$ In addition, "the meeting provides the occasion for board members to pool judgment on issues confronting them." ${ }^{\text {U26 }}$ Ultimately, "[b]oard meetings are concerned with public business, and the school board has a public mission to fulfill." ${ }^{227}$ It is difficult to discern how religious worship is a means to fulfill this "public mission" of addressing important public education issues.

\section{The Short History of the Public School}

The second Part of this Comment will analyze the historical arguments that were the basis for the Court's decision in Marsh v. Chambers. However, before doing so, it is worth noting that any problems with an historical analysis are even more pronounced when the factual setting for the issue at hand-the modern public school-did not exist at the time of the Constitution's framing. ${ }^{128}$ The Supreme Court has often noted the relatively short history of public schools in declining to apply an historical analysis in this context: "[A] historical approach is not useful in determining the proper roles of church and state in public

123 NAtional SCH. PUb. Relations Ass'N, supra note 22, at 5; cf. Society of Separationists, Inc. v. Whitehead, 870 P.2d 916, 930 (Utah 1993) ("Marsh involved prayer before a state legislature whose floor sessions do not involve participation by the public to the degree found in city council meetings.").

${ }^{124}$ See supra Part I.B.1.

${ }^{125}$ Stephen J. KNEZEVICH, AdMinistration of Public Education 324 (3d ed. 1975).

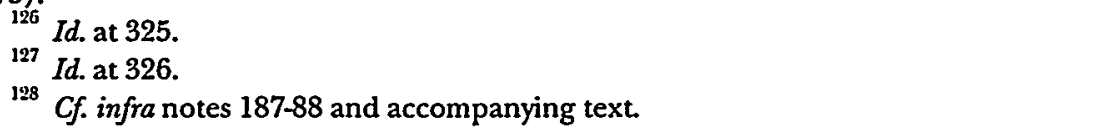


schools, since free public education was virtually nonexistent at the time the Constitution was adopted." ${ }^{129}$ Whether the focus is the general one of public schools, the more specific topic of locally elected public school boards, or the even more specific subject of this Commentinvocations at public school board meetings-it is clear that no such animal existed in 1787 nor, for the most part, even in $1866 .^{130}$

As one education scholar put it, "the haphazard arrangements of the seventeenth, eighteenth, and early nineteenth centuries cannot be considered true progenitors of the school systems we know today." ${ }^{131}$ As late as the first decades of this century, some states still did not have compulsory education laws, ${ }^{132}$ as many as thirty percent of school age children in the South did not attend school at all, ${ }^{133}$ and public schools that did exist were highly homogeneous in character. ${ }^{134}$

Given the attitudes toward non-Protestant religions ${ }^{135}$ and the purpose of what little formal education did exist in the late eighteenth cen-

${ }^{129}$ Edwards v. Aguillard, 482 U.S. 578, 583 n.4 (1987); see also Wallace v. Jaffree, 472 U.S. 38, 80 (1985) (O'Connor, J., concurring in judgment) ("The simple truth is that free public education was virtually nonexistent in the late 18 th century."). Justice Scalia has made the same point in applying the Fourth Amendment to searches and seizures in public schools. See Vernonia Sch. Dist. 47J v. Acton, $115 \mathrm{~S}$. Ct. 2386, 2390 n.l (1995) ("Not until 1852 did Massachusetts, the pioneer in the 'common school' movement, enact a compulsory school-attendance law, and as late as the 1870 's only 14 States had such laws.").

${ }_{130}$ See also infra text accompanying notes 169-71.

191 Michael B. Katz, The Origins of Public Education: A Reassessment, in THE SOClAL HISTORY OF AMERICAN EDUCATION 91, 93 (B. Edward McClellan \& William J. Reese eds., 1988); see also Leo PFEFFER, CHURCH STATE AND FREEDOM 326-30 (rev. ed. 1967) (noting that free, universally open public schools did not begin to develop until well into the 19th century).

${ }^{132}$ See EDGAR W. KNIGHT, EDUCATION IN THE UNITED STATES 501 (3d rev. ed. 1951) (noting that it was not until 1918 that all states had enacted laws mandating compulsory education). It was not until more than a century after the framing of the Constitution that most states created the constitutional right to an education for all (white male) children. See SAMUEL WINDSOR BROWN, THE SECULARIZATION OF AMERICAN EDUCATION 98-102 (1912) (citing education provisions of various state constitutions).

${ }^{139}$ See Patricia AlbJerg Graham, COMmunity and Class in AMERICAN EDU. CATION, 1865-1918, at 15 (1974) (listing by region the percentage of children aged six to fourteen attending school in 1910).

${ }^{134}$ See id. at 9 (discussing the racial, ethnic, economic and religious homogeneity in public schools during the late 19 th and early 20 th centuries).

${ }_{135}$ See, e.g., ROBERT S. ALLEY, SCHOOL PRAYER: THE COURT, THE CONGRESS, AND THE FIRST AMENDMENT 31 (1994) (noting that James Madison, in a letter to Thomas Jefferson, indicated that some in New England opposed the Constitution's prohibition on religious tests as "open[ing] the door for Jews, Turks and infidels"); see also infra note 164 and accompanying text. 
tury, ${ }^{136}$ it is difficult to know whether the Framers would have endorsed prayers at the meetings of an entity (probably unforeseeable in their time) charged with educating not only Protestants, but Catholics, Jews, Muslims, Buddhists, atheists and others. Even if the Framers did approve of legislative prayer, ${ }^{137}$ it requires a great leap of faith or logic to conclude that they approved of prayer at modern public school board meetings. The latter practice not only did not exist at the time of the Framing, but in many cases has been instituted only recently. ${ }^{138}$

Part I of this Comment has concentrated on the public school setting. A parsing of the Supreme Court's consistent line of "religion and public schools" holdings has been coupled with an explanation of the unique role (and short history) of the public school system and the characteristics that distinguish school boards from legislatures. From this analysis, it would appear unlikely that the Court would apply the narrow holding of Marsh to the situation of school board meeting prayers. Nevertheless, as the only legislative prayer case the Court has decided, arguments are inevitably made for extending Marsh to school board meetings. ${ }^{199}$ Therefore, it is helpful to examine more closely the

${ }^{196}$ See, e.g., Scown v. Czarnecki, 106 N.E. 276, 279 (Ill. 1914) (quoting an Illinois ordinance of 1787 , which declared that "[ $r$ ] eligion, morality and knowledge being necessary to good government and the happiness of mankind, schools and the means of education shall forever be encouraged"); see also BROWN, supra note 132, at 98-99 (listing state constitutional provisions from the 18th and 19th centuries with language similar to that in Czarnecki); Edwin Scott Gaustad, Church, State, and Education in Historical Perspective, in RELIGION, THE STATE, AND EDUCATION, supra note 112, at 11, 19-20 (observing that a 19th century Massachusetts law against public school books favoring "any particular religious sect or tenet' .... was only meant to say that the instruction should be broadly Protestant, not narrowly the property of a single church"); $c f$. JOHN HERBERT LAUBACH, SCHOOL PRAYERS: CONGRESS, THE COURTS, AND THE PUBLIC 25-26 (1969) (noting that mid-19th century religious zealots called Horace Mann an atheist because his proposal for "religious instruction" did not include indoctrination of pupils in one particular sect).

${ }_{137}$ See supra text accompanying notes 13-14.

193 See sources cited supra note 16. Whatever controversy may (or may not) have surrounded the issue of legislative chaplains in the early Congresses, the attempt to bring prayer to public school board meetings has been anything but noncontroversial. See infra notes 242-43. This again reflects the transformation from a nation where a homogeneous group of legislators could act upon matters such as "sins, repentance, humiliation, divine service, reformation, mourning, public worship, funerals, true religion, chaplains, etc.," as the Continental Congress did, see PFEFFE, supra note 131, at 265 , to one where even many of the smallest communities contain a sizable population of nonmajority religionists, see generally MARTIN B. BRADLEY ET AL., CHURCHES AND CHURCH MEMBERSHIP IN THE UNITED STATES 1990 (1992) (presenting statistics on the number of adherents to various religions).

${ }^{199}$ See, e.g., Coles v. Cleveland Bd. of Educ., 950 F. Supp. 1337, 1345 (N.D. Ohio 1996) ("The Court is of the view that the facts of this case are more closely associated 
underlying facts and the reasoning that the Court employed in Marsh.

\section{LEGISLATIVE PRAYER}

\section{A. Marsh v. Chambers ${ }^{140}$}

As noted above, the Supreme Court held in Marsh v. Chambers that "the practice of opening [legislative] sessions with prayers by a stateemployed clergyman" did not violate the Establishment Clause of the First Amendment. ${ }^{141}$ In reaching this conclusion, the Court relied almost exclusively on two related arguments: "historical patterns" and "contemporaneous practices."142 The Court briefly discussed certain aspects of the Nebraska legislative prayer in question, finding no constitutional infirmities even though the same Presbyterian chaplain had been employed and paid with tax dollars for an unbroken period of sixteen years and even though the "prayers [were] in the Judeo-Christian tradition." 143

Justice Brennan, joined by Justice Marshall, wrote a lengthy dissent in which he found that legislative prayer violated all three prongs of the Lemon test, ${ }^{144}$ the standard Establishment Clause test at the time of

with the so-called legislative or public body prayer exception articulated in Marsh....").

${ }^{140} 463$ U.S. 783 (1983).

${ }^{141}$ Id. at 786 .

142 Id. at 790. As pointed out by Justice Brennan's dissenting opinion in Marsh, the majority reached its conclusion without analyzing legislative prayer under the standard. Establishment Clause test from Lemon v. Kurtzman, 403 U.S. 602 (1971), discussed infra Part III.A. See Marsh, 463 U.S. at 796 (Brennan, J., dissenting). Interestingly, the majority's analysis ignored Lemon even though the Eighth Circuit's decision, which the Supreme Court reversed, relied explicitly on Lemon in striking down the practice of legislative prayer. See Chambers v. Marsh, 675 F.2d 228, 233-34 (8th Cir. 1982).

${ }^{143}$ Marsh, 463 U.S. at 793. In particular, the Court held that the continuous employment of a single minister from one denomination would be of concern only if the reappointment stemmed from "an impermissible motive" and the content of the chaplain's prayer would be problematic only if it proselytized or advanced or disparaged a particular faith. Id. at 793-95. On the latter point, the Court cited seemingly inconsistent rationales for finding the content of the prayer acceptable, noting the chaplain's abandonment of the explicitly Christian prayers that he gave for the first 15 years of his tenure, id. at 793 n.14, while emphasizing that it was not the Court's job "to embark on a sensitive evaluation or to parse the content of a particular prayer," id. at 795 . But see id. at 823-24 \& n.2 (Stevens, J., dissenting) (noting the "clearly sectarian content of some of the prayers given by Nebraska's chaplain").

${ }^{144}$ See id. at 797-801 (Brennan, J., dissenting). In brief, the Lemon test requires that a governmental practice have a secular purpose, have a primary effect of neither advancing nor inhibiting religion, and not lead to excessive entanglement of government and religion. See Lemon v. Kurtzman, 403 U.S. 602, 612-13 (1971). The test and 
Marsh. Justice Brennan discussed the constitutional principles of state neutrality toward religion and separation of church and state. ${ }^{145} \mathrm{He}$ also directly criticized the majority's historical arguments, declaring that "specific historical practice should not in this case override th[e] clear constitutional imperative." ${ }^{146}$ Finally, Justice Brennan discussed the inherent problems of government-sponsored prayer, noting that, unlike religious notations on coins or in national mottos, "[p]rayer is serious business-serious theological business. ${ }^{\text {"177 }}$

Marsh was seen as both a major departure from the Court's earlier Establishment Clause jurisprudence ${ }^{148}$ and an opening to those who had decried its earlier decisions striking down prayer in school and limiting other governmental religious practices. ${ }^{149}$ The decision remains the Court's only holding to have explicitly approved official prayer in a government setting. ${ }^{150}$

its application to prayer at school board meetings is discussed in fuller detail infra Part III.A.

${ }^{45}$ See Marsh, 463 U.S. at 803-06 (Brennan, J., dissenting) (stating that freedom of conscience, religious autonomy, prevention of the trivialization or degradation of religion, and avoidance of political divisiveness are assured by these principles).

${ }^{146} I d$. at 814; see also id. at 813-17 (arguing, among other things, that the practices of the first Congress should not be dispositive).

147 Id. at 819; see also id. at 818-21 (reviewing various objections religious persons might have to both sectarian and nonsectarian legislative prayers). Justice Stevens's short dissenting opinion made a related point. See id. at 823-24 (Stevens, J., dissenting) (noting that "the tenure of the chaplain must inevitably be conditioned on the acceptability" of the prayers he recites). For a discussion of the content of government-sponsored prayers and the possibilities for "nonsectarian" prayers, see infra Part III.D.1.

${ }^{148}$ See, e.g., SMITH, supra note 16, at 257 ("Marsh makes for a strange fit with the Court's prior decisions..); M. Greg Crumpler, Note, Constitutional Law-Legislative Chaplaincy Program Held Not to Violate the Establishment of Religion Clause-Marsh v. Chambers, _ U.S. _, 103 S. C.t. 3330 (1983), 6 CAMPBell L. REV. 143, 157 (1984) ("[T]he Court's holding that this particular chaplaincy program was constitutional is irreconcilable with previous interpretations of the Establishment Clause and has the potential for throwing Establishment Clause analysis into chaos."); The Supreme Court, 1982 Term-Establishment of Religion: Separation and Accommodation of Church and State: Larkin v. Grendel's Den, Inc. and Marsh v. Chambers, 97 HARV. L. REV. 143, 148 (1983) (predicting that "Marsh will lead to confusion in lower courts and state legislatures regarding the allowable limits of government-sanctioned religious expression").

${ }^{149}$ See, e.g., TERESA L. DONOVAN ET AL., VOluntary SCHOOL PRAYER: Judicial DILEMMA, PROPOSED SOLUTIONS 57 (1984) (arguing that Marsh "indicate[s] that the door is open for a re-evaluation of the religion jurisprudence of recent years"); Serra, supra note 8, at 778 (arguing that the Court is moving toward an Establishment Clause analysis that is more tolerant of "government-sponsored religious practices").

${ }_{150}$ Most recently, the Court rejected prayer at public school graduation ceremonies in Lee v. Weisman, 505 U.S. 577 (1992). Cf. Moore v. Ingrebretsen, 117 S. Ct. 388 (1996), denying cert. sub nom. to Ingebretsen v. Jackson Public Sch. Dist., 88 F.3d 274, 
It is highly questionable, given the Court's failure to abandon its stricter Establishment Clause tests for a Marsh-type historical analysis, ${ }^{152}$ whether it would apply Marsh in the context of public school board meetings. In addition, the short history of public schools makes an historical analysis even more inappropriate in this setting than in other settings, such as the state legislative prayer context. ${ }^{152}$ However, because it might be argued that the decision in Marsh provides the answer to the question of the constitutionality of school board prayer, it is important to analyze the Court's two justifications for its holding in Marsh before independently analyzing the issue of school board prayer under the Court's major Establishment Clause tests.

\section{Historical Patterns}

"Standing alone, historical patterns cannot justify contemporary violations of constitutional guarantees," 153 the Court said in Marsh, before ignoring its own admonition. At least two problems exist with the idea that longstanding historical patterns can justify current violations of the Constitution. ${ }^{154}$

\section{a. Adverse Possession of the Constitution}

First, from a purely logical perspective, past actions should have no bearing on a constitutional analysis of current activity. A half-century of unconstitutional police misconduct would not grant a law enforcement

279 (5th Cir. 1996) (finding Mississippi's school prayer statute unconstitutional). But cf. Jones v. Clear Creek Indep. Sch. Dist., 508 U.S. 967 (1993), denying cert. to 977 F.2d 963, 972 (5th Cir. 1992) (upholding practice of prayer at public school graduations when students were permitted to vote for the prayer).

${ }^{151}$ See, e.g., Louis Hatcher, Comment, Lofty Neutrality: The Traditional Pregame Invocation Versus the First Amendment's Establishment Clause, 20 CUMB. L. REV. 687, 710 (1989. 1990) ("The approach taken in Marsh has been strictly limited in its subsequent application, being applied rarely, and then only in those cases where an aspect of history and tradition exists.").

${ }^{152}$ See supra Part I.B.3.

${ }^{153}$ Marsh v. Chambers, 463 U.S. 783, 790 (1983).

${ }^{154}$ The discussion which follows in Parts II.A.1-2 in no way covers the entire debate over the use of history in constitutional interpretation. This issue is part of the larger debate among academics, jurists and practitioners over the Constitution's meaning. See generally MICHAEL J. GERHARDT \& THOMAS D. ROWE, JR., CONSTITUTIONAL THEORY: ARGUMENTS AND PERSPECTIVES 39-193 (1993) (discussing the ways in which jurists and theorists argue about different sources of constitutional decisionmaking); Daniel A. Farber, The Originalism Debate: A Guide for the Perplexed, 49 OHIO ST. L.J. 1085 (1989). This Comment will address only those aspects of the debate that are particularly applicable to the Court's reasoning in Marsh and to the issue of school board prayer. 
agency adverse possession of the constitutional prohibitions on illegal searches and seizures or violations of due process. ${ }^{155}$ If the current government conduct (whether police brutality or legislative prayer) violates a constitutional provision, it is unconstitutional regardless of its pedigree.

The idea that those who violate the Constitution can, in effect, gain immunity for their longstanding transgressions is particularly troublesome, given that those who attempt to challenge unconstitutional conduct may be subject to reprobation which deters such challenges. ${ }^{156}$ Some supporters of public prayer even advise those opposed to such practices to protest silently, ${ }^{157}$ which, ironically, provides greater support for the contention that the religious sentiments expressed are simply those "widely held among the people." 158 Through this process, alleg-

${ }^{15 J}$ Cf., e.g., PHILliP J. COOPER, HARD JudiCIAL CHOICES 297-98 (1988) (noting constitutional violations by police in Philadelphia in the 1950s); Rizzo v. Goode, 423 U.S. 362, 382 (1976) (Blackmun, J., dissenting) (noting district court findings of similar problems in early 1970s); NAACP v. City of Philadelphia, No. 96-6045 (E.D. Pa. filed Sept. 4, 1996) (Settlement and Monitoring Agreement between community organizations and city aimed at reforming the Philadelphia Police Department, in 1996).

${ }^{150}$ See, e.g., Nadine Strossen, How Much God in the Schools? A Discussion of Religion's Role in the Classroom, 4 WM. \& MARY BILL RTS. J. 607, 610-15 (1995) ("Of all the issues the ACLU takes on ... by far the most volatile issue is that of school prayer. Aside from our efforts to abolish the death penalty, it is the only issue that elicits death threats." (internal quotations and citations omitted)); see also LAUBACH, supra note 136, at 26-29 (noting that during the mid-19th century in the United States, clashes between Protestants and Catholics over the choice of Bibles and the religious teachings to be used in public schools resulted in riots and deaths); Neil G. McCluskey, The New Secularity and the Requirements of Pluralism, in RELIGION AND PUBLIC EDUCATION, supra note 112, at 231, 244 ("The voices of moderates willing to discuss adaptation and compromise were drowned out by the bigots and extremists ....").

${ }^{157}$ Cf. Lee v. Weisman, 505 U.S. 577, 637 (1992) (Scalia, J., dissenting) (describing as "ludicrous" the notion that sitting silently during a prayer constitutes joining in the prayer).

${ }_{138}$ Marsh v. Chambers, 463 U.S. 783, 792 (1983) (noting that "the practice of opening legislative sessions with prayer has become part of the fabric of our society"). But see Strossen, supra note 156, at 610 ("Especially given the political pressures on school boards to bow to majoritarian forces, the religious liberty of individuals and minority groups is always fragile."); Developments in the Law-Religion and the State: Accommodation of Religion in Public Institutions, 100 HARV. L. REV. 1606, 1656 (1987) ("The establishment clause object of protecting religious minorities from majoritarian imposition of religion is undermined if the majority's views govern the determination of whether the majority's accommodation of its own 'widely held' religious beliefs violates the clause's guarantee.").

Under the logic of Marsh, the majority determines which beliefs are "widely held," acts accordingly, suppresses any dissenting voices, and maintains its own practices for decades-allowing the Supreme Court to conclude that this "unbroken practice... gives abundant assurance that there is no real threat" to the Establishment Clause. Marsh, 463 U.S. at 795. But see FENwICK, supra note 122, at 164 (noting those 
edly unconstitutional conduct continues unopposed (or opposed but persisted in nonetheless) for decades, eventually gaining constitutional acceptance and becoming part of the foundation of support for more serious constitutional transgressions. ${ }^{159}$ Without this "slippery slope," it is clear that the logic of Marsh would not apply to the context of public school board meetings because the history of school boards themselves is relatively short ${ }^{160}$ and the specific practice of opening school board meetings with prayer is largely of recent vintage. ${ }^{161}$

\section{b. Changing Times}

The second problem with the "historical patterns" argument is that it ignores changes in society and social attitudes. ${ }^{162}$ One can offer numerous examples in which changes in social relationships, cultural attitudes or material conditions led to the updating of constitutional jurisprudence. ${ }^{163}$ In the two areas most pertinent to this Comment, religion

arguments against school prayer that are based on the belief that school prayer tends to alienate those of minority religions); Joe Loconte, Lead Us Not into Temptation: $A$ Christian Case Against School Prayer, POL'Y REV., Winter 1995, at 24, 25 (noting that many Jews "were deeply troubled by the Protestant overtones in classroomsincluding prayers in the name of Christ and readings from the New Testament").

${ }_{159}$ As one scholar noted:

Government proclamations of days of thanksgiving and occasionally prayer are another illustration of ceremonial acts of government which are of slight intrinsic significance but are of great importance in the use to which they are put as precedents to justify far more substantial encroachments of government on religious affairs or religion on government affairs. As a practical matter there is no way in which the constitutionality of such proclamations can legally be tested .... Accordingly their constitutionality is generally taken for granted, and they become another item of evidence in the "common sense" interpretation of the First Amendment.

PFEFFER, supra note 131, at 265. See generally id. at 238-50 (arguing that government references to God are not inherently problematic but are nonetheless harmful because they provide precedential support for further violations of the Establishment Clause). For recent evidence of Pfeffer's theory in practice, see County of Allegheny $v$. $A C L U, 492$ U.S. 573, 670-73 \& n.9 (1989) (opinion of Kennedy, J.) (citing Thanksgiving proclamations and prayers at presidential inaugurations in support of an argument for allowing additional religious expression by government).

${ }^{160}$ See supra Part I.B.3.

161 See sources cited supra note 16.

${ }^{162}$ In a dissenting opinion written the year before Marsh, Chief Justice Burger, the author of the Marsh decision, made the same point. See Harlow v. Fitzgerald, 457 U.S. 800, 823 (1982) (Burger, C.J., dissenting) (arguing that immunity for presidential aides should be examined in the same way that the Court had examined immunity for legislative aides: "in the context of the Constitution taken as a whole and in light of 20th-century realities" (emphasis added)).

${ }^{163}$ Seventy years ago, Justice Oliver Wendell Holmes, along with seven of his Su- 
and public education, changing attitudes also indicate the weakness of "historical patterns" arguments to support constitutional violations.

Throughout the first century of this nation's history, the prohibition on an establishment of religion was not seen as incompatible with the declaration that the United States "is a Christian nation." Tod Tay, even those advocating a view of the Establishment Clause that permits nonpreferential government support for religion in general would hesitate before declaring the nation a Christian one. ${ }^{165}$ Religious pluralism in the United States today is almost certainly much greater than it was a century or two centuries ago. ${ }^{166}$ Yet when government actions or judicial determinations are justified by reference to the practices of these less diverse and less tolerant eras, the effect is to nullify the broadening of American culture and to codify the attitudes of an obsolete society.

preme Court colleagues, sanctioned the forced sterilization of the mentally ill. See Buck v. Bell, 274 U.S. 200, 207 (1927) (justifying the practice with the famous line that "[t]hree génerations of imbeciles are enough"). Today, forced sterilization based solely on unsupported allegations of mental illness would be seen not only as abhorrent, but as unconstitutional. Cf. Cleveland Bd. of Educ. v. LaFleur, 414 U.S. 632, 63940 (1974) (noting that "freedom of personal choice" regarding matters of "family life," such as pregnancy, is protected by the Constitution).

${ }^{164}$ Church of the Holy Trinity v. United States, 143 U.S. 457, 471 (1892) (basing this observation on "a view of American life, as expressed by its laws, its business, its customs, and its society"); see also Davis v. Beason, 133 U.S. 333, 343 (1890) (noting that the government may punish acts "recognized by the general consent of the Christian world in modern times as proper matters for prohibitory legislation"); Vidal v. Girard's Ex'r, 43 U.S. (2 How.) 127, 199 (1844) (noting that "a devise in Pennsylvania for the establishment of a school or college, for the propagation of Judaism, or Deism, or any other form of infidelity ... is not to be presumed to exist in a Christian country").

${ }^{165}$ See, e.g., Lee v. Weisman, 505 U.S. 577, 641 (1992) (Scalia, J., dissenting) (acknowledging as an unconstitutional establishment of religion government action that endorses certain "details upon which men and women who believe in a benevolent, omnipotent Creator and Ruler of the world are known to differ (for example, the Divinity of Christ)").

${ }^{166}$ See, e.g., THE EnCYClopedia OF AMERICAN RELigions: Religious CreEdS at xxixxii (J. Gordon Melton ed., 1988) (noting that the encyclopedia lists more than 450 different creeds in 22 different "religious families"). In 1990, one study found that almost half of the population of the United States was not an "adherent" of a Christian church. See BRADLEY ET AL., supra note 138, at xiv, 1-3 (finding that "all members, including full members, their children and the estimated number of other regular participants" in 134 Christian church bodies is less than $56 \%$ of the total population). Clearly, many of the other $44 \%$ consider themselves Christians, if not members of a church. Still, a large minority of Americans are neither "adherents" of a Christian church nor nonparticipating Christians. See, e.g., GalluP, supra note 32, at 25, 42, 47 (finding that 17\% of Americans in 1994-1995 identified themselves as neither Catholic nor Protestant).

${ }^{167}$ Presumably, the codification will become permanent until a sufficiently large minority of constituents of the relevant government entity convince that entity to alter its longstanding practice. Cf. Employment Div., Dep't of Human Resources v. Smith, 
In the area of public schools, the expectations for the institution, the nature of the student body, and the school's relationship to the larger community have changed tremendously. Once again, one must ask if practices that may have been seldom challenged ${ }^{168}$ in the context of eighteenth and nineteenth century "public schools" are immune from appropriate constitutional analysis in the context of the modern pluralistic public school, given that "the traditional role of the public or common school in the transmission of agreed-upon moral and spiritual values has almost totally changed." ${ }^{169}$ In fact, the public school has undergone a transformation from the early nineteenth century "nondenominational" Protestant school to the modern, truly common school. ${ }^{170}$ At the end of the nineteenth century, the top education official in the federal government, A.P. Peabody, said:

We are by profession a Christian people. We recognize the great principles of religion in the devotional services in our legislatures and our courts of justice. Shall our children be trained as citizens without the inculcation of these fundamental religious ideas which will impress upon them the significance of prayer and the dread solemnity of an oath ${ }^{171}$

Constitutional jurisprudence that relies on historical practices contemporaneous with such sentiments may result in outcomes desirable to those who believe "we are ... a Christian people," but such jurispru-

494 U.S. 872, 890 (1990) ("It may fairly be said that leaving accommodation to the political process will place at a relative disadvantage those religious practices that are not widely engaged in ...."). For criticism of the "majority rules" principle in the context of government religious activity, see Cammack v. Waihee, 944 F.2d 466, 467 (9th Cir. 1991) ("While official recognition of any or all religions is prohibited by the constitution, the preference of the majority religion over all others is certainly among the principal offenses the first amendment condemns." ), dissenting from denial of reh'g en banc 932 F.2d 765 (9th Cir. 1991).

${ }^{168}$ Although it is impossible to determine how much silent opposition existed to government practices offensive to minority religions, occasional protests did occur. See PFEFFER, supra note 131, at 436-44 (discussing disputes over Bible reading in schools, from the 1840s through 1880s); see also supra note 156.

${ }^{169}$ McCluskey, supra note 156, at 233-34.

170 See id. at 233-38; cf. Talcot Parsons, The Nature of American Pluralism, in RELIGION AND PUBLIC EDUCATION, supra note 112, at 249, 250 ("[American society] has moved from largely negative toleration of non-Protestants to their inclusion in a denominationally pluralistic community, the pluralism of which comprises all the most important religious groups of Western history."). See generally BROWN, supra note 132, at 1-3 (discussing factors behind the gradual disappearance of religious influences on public education).

${ }^{171}$ A.P. Peabody, Report of the United States Commissioner of Education for the Year 1897-1898, at 1563-64 (quoted in Arthur Gilbert, Reactions and Resources, in RELIGION AND PUBLIC EDUCATION, supra note 112, at 37, 42). 
dence risks closing the modern courthouse-or schoolhouse-door on anyone not within A.P. Peabody's limited definition of society.

\section{Contemporaneous Practices}

Analysis of the practices of the Constitution's Framers is not an uncommon tool of constitutional interpretation. As the Court argued in Marsh, perhaps oversimplifying, "their actions reveal their intent." Nevertheless, this mode of analysis contains a number of problems.

\section{a. The Infallible Framers?}

Most fundamentally, it is not necessarily true that the men who made up the first Congresses and framed the First Amendment were always consistent in their constitutional handiwork and their legislative actions. In at least one prominent case, the Supreme Court found otherwise. ${ }^{173}$ Chief Justice Marshall held that the judicial authority granted the Court, by a 1789 act passed by the first Congress, "to issue writs of mandamus to public officers, appears not to be warranted by the constitution." ${ }^{\text {174 }}$ Apparently, "their actions" in passing the Judiciary Act $^{175}$ did not "reveal their intent" regarding Article III of the Constitution.

There are a number of reasons why the actions of the Framers might not be good indications of their intent. First, whatever honor may be due them, the Framers were politicians. Creating a constitutional bulwark against government-religion entanglement may have been both laudable and popular, but eliminating practices that supposedly demonstrated a legislator's belief in the Almighty probably was not worth the political fallout in the 1789 Congress any more than it would have been in the 1983 Nebraska legislature. ${ }^{176}$ Particularly given the

172 Marsh v. Chambers, 463 U.S. 783, 790 (1983).

173 See Marbury v. Madison, 5 U.S. (1 Cranch) 137 (1803) (holding that the Judiciary Act of 1789 , as written by the first Congress, granted unconstitutional authority to the judicial branch).

174 Id. at 176. (1994)).

${ }^{175}$ Judiciary Act, ch. 20, $\$ 33,1$ Stat. 73 (1789) (current version at 18 U.S.C. $§ 3041$

${ }_{176}$ James Madison was well aware that politicians might not adhere to the letter or spirit of their own constitutional creations. See Letter from James Madison to Thomas Jefferson (Oct. 17, 1788), in 5 THE WRITINGS OF JAMES MADISON 269, 272 (Gaillard Hunt ed., 1904) ("[E]xperience proves the inefficacy of a bill of rights on those occasions when its controul is most needed. Repeated violations of these parchment barriers have been committed by overbearing majorities in every State."). In the specific context of religion, the difficulty of reconciling electability by a majority with the protection of minority views has been noted by modern commentators. See MILLER, supra 
Constitution's elimination of any religious test for office, ${ }^{177}$ the pressure on politicians to demonstrate their godliness in some other manner may have been too strong to resist.

Second, as with the Judiciary Act, the Framers may have taken legislative actions that they believed to be constitutional (or whose constitutionality they may have never considered), but whose consistency with the Constitution becomes more questionable under the light of judicial analysis and the reflection provided by the passage of time. ${ }^{178}$ Moreover, certain practices, including the use of legislative chaplains, predated the framing of the Constitution and may have been carried forward without much thought as to how the new constitutional framework affected their status. ${ }^{17}$

note 1 , at $41-46$ ("The careful inoffensiveness of public office leads straight to the semi-secular religion or the semi-religious secularism which is both a convenient compromise among the wide variety of positions to which officialdom must be attentive and a very popular position in its own right."); see also PAUL BLANSHARD, GOD AND MAN IN WASHINGTON 96 (1960) ("Th[e] technique of accommodation employed by Congressmen in handling religious issues .... is part of the process of avoidance and adjustment that every successful politician must master if he wishes to stay in office in a democracy.").

This point holds true as well for the President, whose religious proclamations are often cited in efforts to expand the scope of permissible government religious exercise. See supra note 159; of. Clinton, supra note 31.

${ }^{177}$ See U.S. CONST. art. VI, $\S 3$ (" $[\mathrm{N}]$ o religious Test shall ever be required as a Qualification to any Office or public Trust under the United States.").

${ }^{178}$ Again, the best example is Marbury v. Madison. For another example, consider the Civil Rights Cases, 109 U.S. 3 (1883). Less than a decade after passage of the Fourteenth Amendment, Congress passed a Civil Rights Act aimed at, among other things, private discrimination, obviously believing the Amendment granted it the power to do so. The Court held otherwise, apparently not convinced that legislators were the best interpreters of the scope of a constitutional provision they had so recently framed. See id. at 10-11. In some cases, the Framers themselves may have disagreed, upon reflection, with their own alleged intent. Compare Marsh v. Chambers, 463 U.S. 783, 788 n.8 (1983) (noting that James Madison "voted for the bill authorizing payment of [Congressional] chaplains"), with Elizabeth Fleet ed., Madison's "Detached Memoranda," 3 WM. \& MARY Q. 534, 558 (1946) (excerpting an 1820 letter by James Madison which asserted that legislative chaplaincies were violations of the Establishment Clause, as well as "a palpable violation of equal rights").

In Lee v. Weisman, Justice Souter made the same point regarding the Free Speech Clause, noting that " $[\mathrm{t}] \mathrm{en}$ years after proposing the First Amendment, Congress passed the Alien and Sedition Acts, measures patently unconstitutional by modern standards." 505 U.S. 577, 626 (1992) (Souter, J., concurring). Justice Souter noted that such practices of the first Congresses could have indicated "at best, that the Framers simply did not share a common understanding" of certain constitutional provisions or "at worst, that they, like other politicians, could raise constitutional ideals one day and turn their backs on them the next." Id.

${ }^{179}$ In at least one case, the Supreme Court found unconstitutional just such a practice which predated the Constitution and continued in force following its passage. 
Finally, it is impossible to determine, from their actions or from other clues, what the "intent" of the Framers was, because it is impossible for an entire body of legislators (or, for that matter, an entire nation) to have a single "intent." Indeed, it is entirely plausible that the Framers' "intent" was to provide an overall structure of national government and a system of federalism, with certain clear limitations, prohibitions and rights, and other general principles to guide future generations. ${ }^{181}$

\section{b. The Static Constitution?}

As discussed above, ${ }^{182}$ one flaw in pure history-based constitutional

See McDaniel v. Paty, 435 U.S. 618, 622-25 (1978) (plurality opinion) (invalidating state constitutional provision barring ministers from holding public office despite the fact that it was a practice "carried from England by seven of the original states" and continued in a number of states well into the 19 th century).

${ }^{180}$ The Court has acknowledged this fact when attempting to discern the motive of legislators. See, e.g., Palmer v. Thompson, 403 U.S. 217, 225 (1971) ("It is difficult or impossible for any court to determine the 'sole' or 'dominant' motivation behind the choices of a group of legislators.").

To avoid this problem with regard to the First Amendment, Justices and commentators often resort to the alleged intent of James Madison to determine the intent of the Amendment. Aside from the obvious concern with ascribing the intent of one (admittedly important) Framer to the entire Congress and the states, there is less than universal agreement regarding Madison's own actions and intent. Compare Marsh v. Chambers, 463 U.S. 783, 788 n.8 (1983) ("It bears note that James Madison ... voted for the bill authorizing payment of the chaplains."), with LEONARD W. LEVY, THE. ESTABLISHMENT CLAUSE: RELIGION AND THE FIRST AMENDMENT 120 (2d ed. rev. 1994) (noting that there is no evidence that Madison voted for the bill authorizing payment of legislative chaplains), and SMITH, supra note 16, at 244 ("The basic principles infusing Madison's objection [in 1820] to a paid chaplaincy are identical to those that remained throughout his lifetime.").

${ }^{181}$ Given the prevalence in the 18th century of both natural law and common law methods of judicial analysis, it seems particularly inappropriate to imbue the Framers with the "intent" of codifying specific practices as permissible (or prohibitory) for time immemorial. See Suzanna Sherry, The Founders' Unuritten Constitution, 54 U. CHI. L. REV. 1127, 1145 (1987) (noting that the colonists believed that "judges were to look to natural law and the inherent rights of man, as well as to the written constitution, in determining the validity of a statute"). Consider the terminology used in many of the constitutional provisions, such as "respecting," and "abridging," U.S. CONST. amend. I, "unreasonable," and "probable cause," id. amend. IV, "public danger," id. amend. V. These are hardly the phrases one would use if the intent was to establish black-andwhite rules, having the exact same meaning when applied to similar facts, whether in 1787 or in 1983. See McCulloch v. Maryland, 17 U.S. (4 Wheat.) 316, 407 (1819) (finding that a constitution requires "that only its great outlines should be marked, its important objects designated, and the minor ingredients which compose those objects, be deduced from the nature of the objects themselves").

${ }^{182}$ For a discussion of the role of historical changes in constitutional interpretation, see supra notes 163-71 and accompanying text. 
analysis is the failure to acknowledge that social, cultural and material conditions change dramatically over decades, let alone over centuries. Given the Framers' awareness of both the practical difficulties and the inappropriateness of regular constitutional modification, ${ }^{183}$ along with their intention to provide a document as useful to future generations as to their own, ${ }^{184}$ it is not always wise to use their conduct during the eighteenth (or nineteenth) century to determine what is constitutional today.

On numerous occasions, the Court has recognized this reality, modifying an interpretation of the Constitution which is no longer consistent with social, cultural or material realities. ${ }^{185}$ Given the need of the Constitution to speak to modern times, as well as colonial ones, this modification is sometimes necessary even when the original interpretation of a constitutional provision appears supported by actions of the provision's Framers. ${ }^{186}$

${ }^{185}$ See U.S. CONST. art. V (detailing supermajoritarian requirements for amending the Constitution); see also Marbury v. Madison, 5 U.S. (1 Cranch) 137, 177 (1803) ("The constitution is... a superior, paramount law, unchangeable by ordinary means ....").

${ }^{184}$ See U.S. CONST. preamble (indicating the purpose of the Constitution as "secur[ing] the Blessings of Liberty to ourselves and our Posterity" (emphasis added)).

${ }^{185}$ In Justice Brandeis's oft-quoted words, "in cases involving the Federal Constitution, where correction through legislative action is practically impossible, this court has often overruled its earlier decisions." Burnet v. Coronado Oil \& Gas Co., 285 U.S. 393, 406-07 (1932) (Brandeis, J., dissenting) (citation omitted). In determining whether to alter its interpretation of the Constitution, one consideration the Court has used is whether an earlier decision's "premises of fact have so far changed ... as to render its central holding somehow irrelevant or unjustifiable in dealing with the issue it addressed." Planned Parenthood of Southeastern Pa. v. Casey, 505 U.S. 833, 855 (1992).

${ }^{186}$ In the same Congress in which the Fourteenth Amendment was framed, a bill was passed providing for the funding of segregated schools in the District of Columbia. See An Act Relating to Public Schools in the District of Columbia, ch. 217, 14 Stat. 216 (1866). This "contemporaneous practice" of segregation was given a stamp of approval by the Supreme Court in the years following the Amendment's passage. See, e.g., Plessy v. Ferguson, 163 U.S. 537, 551-52 (1896) (finding segregation consistent with the Fourteenth Amendment). Yet by the middle of the next century, the same Fourteenth Amendment was held to prohibit segregated schools. See Brown v. Board of Educ., 347 U.S. 483, 495 (1954) (finding that separate educational facilities violate the Fourteenth Amendment); see also Bolling v. Sharpe, 347 U.S. 497, 500 (1954) (finding that segregated schools in the District of Columbia violate the Fifth Amendment's Due Process Clause). It is worth noting, in light of the discussion of "historical patterns," see supra Part II.A.1, that segregation was a centuries-long practice (including its forerunner, slavery) at least as "traditional" and entrenched as legislative prayer. See, e.g., Griffin v. Prince Edward County Sch. Bd., 377 U.S. 218, 222-23 (1964) (closing of public schools to avoid desegregation); Cooper v. Aaron, 358 U.S. 1, 4 (1958) (resistance by the state of Arkansas to the invalidation of segregated schools). 
In addition, the Framers probably could not have anticipated every future circumstance that would require constitutional adjudication. They most likely did not foresee such modern phenomena as the personal computer or the automobile. Yet the Constitution they created must speak to these issues even if the Framers themselves could not. ${ }^{187}$ Similarly, most of the Framers probably did not foresee the wide diversity of religious (and irreligious) viewpoints, beliefs and faiths that would arise in (or emigrate to) their new nation. Just as the Court cannot abstain from interpreting the Constitution's application to personal computers or automobiles, it should not limit its interpretation of the Establishment Clause to an examination of the practices of political leaders who acted without knowledge of the religiously pluralistic nation to come. One First Amendment scholar made this point recently in relation to the topic of legislative chaplains and Madison's alleged support for the same:

Perhaps, in a nation with a predominantly Christian population and with a Congress almost totally of that persuasion, Mr. Madison felt confrontation on this point was a collision on an unessential issue. We do not know, but in [today's] multicultural mix... Madison just might have seen the chaplaincy as indeed a collision over an essential point. We don't know, and we must pose the question for ourselves, not for our distinguished forebear.

In short, looking to the eighteenth or even nineteenth century to determine what is constitutionally permissible today would lead to a number of results that are almost universally considered unacceptable. ${ }^{189}$ The point is not that contemporaneous practices are irrelevant, but simply that they are far from determinative of what the Constitution

${ }^{187}$ See, e.g., BMW of N. Am., Inc. v. Gore, 116 S. Ct. 1589, 1598 (1996) (holding that a $\$ 2$ million punitive damages award against an automobile manufacturer for nondisclosure of a product defect was unconstitutionally "excessive"); ACLU v. Reno, 929 F. Supp. 824, 849 (E.D. Pa. 1996) (holding that portions of a federal statute regulating content on the Internet were unconstitutional under the First Amendment Free Speech Clause), prob. juris. noted, 117 S. Ct. 554 (1996); see also Carroll v. United States, 267 U.S. 132, 162 (1925) (creating "automobile exception" to Fourth Amendment warrant requirement).

I8s ALLEY, supra note 135, at 67-68; cf. LEVY, supra note 180, at 117 (“'S] trict construction of the First Amendment, if ever taken seriously, would lead to the destruction of basic rights."); Malla Pollack, Prayer in Public Schools: Without Heat, How Can There Be Light?, 15 QLR 163, 183-84 (1995) (arguing that a true adherence to the Framer's practices and intent regarding religious freedom and establishment of religion would lead to protection only for Christians (and possibly only Protestants), a result clearly at odds with any modern judicial interpretation of the First Amendment).

${ }^{189}$ See, e.g., supra note 186. 
means in the context of today's world. ${ }^{190}$

\section{B. Other Government Prayer Cases}

As a bridge between the preceding analysis of Marsh and an independent analysis of school board prayer, ${ }^{191}$ it would be useful briefly to survey the handful of decisions by state and lower federal courts that have addressed the issue of local legislative prayer.

\section{Pre-Marsh Cases}

Fifteen years before the Supreme Court's decision in Marsh, the New Hampshire Supreme Court held, in Lincoln v. Page, ${ }^{192}$ that the practice of "inviting various local clergymen to open the annual and special meetings of [a] town with an invocation" was constitutional. ${ }^{193}$ The court's short opinion relied primarily on the specific facts of the case $^{194}$ and the court's belief that "any and every reference to the Deity [does not] constitut[e] an establishment of religion" under the First Amendment ${ }^{195}$ More than a decade later, two courts would decide legislative prayer cases within three months of each other. In the first, Bogen v. Doty, ${ }^{196}$ a federal appeals court affirmed a district court's holding that a Minnesota county's practice of "inviting a local clergyman to give a prayer immediately prior to the commencement of each Board meeting" did not violate the Establishment Clause. ${ }^{197}$ After reviewing facts similar to those in Lincoln, the court noted that the Supreme Court had recognized "a corridor where certain practices that affect re-

${ }^{190}$ At his Supreme Court confirmation hearing, Justice Breyer made a similar point when asked whether he would look to historical patterns to analyze Establishment Clause questions, explaining that "of course you look at history, and you look at tradition, and you look at the current world as we live [in] it in the United States." The Nomination of Stephen Breyer to the Supreme Court: Hearings Before the Senate Comm. on the Judiciary, 103d Cong. 123 (1994).

\footnotetext{
191 See infra Part III.

192 241 A.2d 799 (N.H. 1968).

193 Id.
}

${ }^{194}$ For example, the court found significant the rotation of clergy, the lack of any public expenditures to support the invocation, and the fact that the invocation was "not composed, selected or approved" by any government official or a part of the official agenda of the town meeting. Id. at 800 .

${ }^{195}$ The court listed the familiar litany of "religious references in proclamations by mayors, governors and presidents." Id. But see supra note 159 and accompanying text (describing process by which such unchallengeable religious references are used to justify greater incursions on First Amendment rights).

196598 F.2d 1110 (8th Cir. 1979).
Id. at 1112 (footnote omitted). 
ligion in some manner, or carry a religious connotation, are permissible in some phases of our governmental operation."198 The court found no Supreme Court cases on point, applied the Lemon test, and found no constitutional problem. ${ }^{1 \times 9}$

In the second 1979 case, Colo v. Treasurer Es Receiver General ${ }^{200}$ the Massachusetts Supreme Judicial Court held that the state legislature's practice of opening its sessions with prayer did not present a constitutional problem. ${ }^{201}$ Although this decision was obviously superseded (and its holding indirectly affirmed) by the decision on the same issue in Marsh, it is important for at least one reason-the fact that the Massachusetts court would later distinguish its decision in this case from situations dealing with public schools. For example, in Kent v. Commissioner of Education, ${ }^{202}$ the court interpreted Supreme Court precedents as "prohibit[ing] religious observances on public school property even when these are nondenominational." ${ }^{203}$ Refusing to apply its earlier legislative prayer decision, it invalidated a state statute allowing for prayers led by student volunteers despite the fact that the court found no evidence that the pupils mistook the prayer for part of the official school day. ${ }^{204}$

In a case decided just two years prior to Marsh, the New Jersey Supreme Court gave its stamp of approval to local municipality prayer, in

198 Id. at 1113.

199 The court listed the secular purpose and the primary effect of the invocations as "establishing a solemn atmosphere and serious tone for the board meetings." Id. As to the entanglement prong, the court noted the potential for divisiveness inherent in the practice, but did "not see this divisive potential as being of the same caliber as the annual appropriation of public funds anticipated but forbidden in Lemon $v$. Kurtzman." Id. at 1114.

It is interesting to note one district court's interpretation of the decision in Bogen, when presented with the argument (before the Supreme Court had decided the issue) that graduation prayers were constitutional under Bogen:

[Bogen] rested on a very scanty stipulation of facts, and the case must be viewed in its slim factual context. The case does not stand for the broad proposition that any governmental public function or ceremony may constitutionally be opened with a religious invocation. In fact, the court warned of the "quagmire" the county was near.

Graham v. Central Community Sch. Dist., 608 F. Supp. 531, 536 (S.D. Iowa 1985).

392 N.E.2d 1195 (Mass. 1979).

${ }^{201}$ See id. at 1201 (stating that "[neither] the Massachusetts [nor] United States Constitutions require the cessation of the practices challenged here").

202402 N.E.2d 1340 (Mass. 1980).

203 Id. at 1343.

${ }^{204}$ See id. at $1345 \&$ n.13. 
Marsa $v$. Wermik ${ }^{205}$ At the time the practice was challenged, members of the borough council gave the invocations, although previously local clergy had been invited to give invocations, as in Lincoln and Bogen. ${ }^{206}$ The court cited prior Supreme Court dicta on the constitutionality of "courts and legislatures open[ing] official sessions with prayer or the mention of God, ${ }^{207}$ and proceeded to affirm the trial court's findings of a legitimate secular purpose $\mathrm{e}^{208}$ and no primary effect of advancing religion. ${ }^{209}$

\section{Post-Marsh Cases}

Not surprisingly, there have been fewer reported legislative prayer cases since the Supreme Court's decision in Marsh. In a 1988 case, the Eighth Circuit found no constitutional violation under the particular facts of a government hospital's chaplaincy program, but rejected the notion that the historical analysis in Marsh "support[s] a rule permit-

${ }^{205} 430$ A.2d 888 (N.J. 1981).

${ }^{206}$ See id. at 891.

${ }^{207} I d$. at 895 (citing School Dist. of Abington Township v. Schempp, 374 U.S. 203, 212-13 (1963)); see also id. at 899 (listing state and federal legislative invocations, "In God We Trust" inscription on coins, and use of "God" in Pledge of Allegiance). But see PFEFFE, supra note 131, at 238-42, 265 (arguing that references to God or Christ in official utterances or acts do not "justify practices that raise substantial and practical state-church problems").

${ }^{208}$ The court found "it significant that there has been no express avowal that the purpose of the opening exercise is religious in whole or in part." Marsa, $430 \mathrm{~A} .2 \mathrm{~d}$ at 896. The problem with this reasoning is that almost two decades after the Court in Schempp first discussed the "secular purpose" prong and a decade after it was codified in Lemon, it would be a monumental event for a government official to profess to a religious purpose in any official action. The court also noted that the "opening exercises do not purport to be part of a religious program. They are part of a municipal legislative session." Id. This, however, assumes away the heart of the plaintiff's complaint, that prayer should remain as "part of a religious program" and not as "part of a municipal legislative session." Id.

${ }^{209}$ In its analysis of the effects prong, the court again relied on circular reasoning to conclude that the municipal prayer did not have a primary effect of advancing religion:

The exercise in its contextual setting is not suggestive of religion or religious ritual; it is conducted as part of a legislative session before a local legislative body. While the opening exercise is conducted by individual council members, and to that extent is under an official aegis, it does not purport to be otherwise officially sponsored or authorized ....

$I d$. at 899. Again, the court essentially rejected a challenge to legislative prayer because it was legislative prayer. Further, it somehow found prayer by government officials during official government meetings not to be "officially sponsored or authorized." Id. 
ting state sponsored chaplaincies of any stripe."210 The Fourth Circuit similarly declined to apply Marsh in a government prayer case, finding a state judge's practice of opening his court sessions with prayer unconstitutional under a Lemon analysis. ${ }^{211}$ The court read Marsh as "predicated on the particular historical circumstances presented in that case" ${ }^{212}$ and found, even under a broader reading of Marsh, that it was "difficult to say that prayer by a judge in the courtroom is comparable to legislative prayer." ${ }^{213}$ Finally, in 1993, a state supreme court upheld, against a state constitutional challenge, a municipality's custom of opening meetings with an invocation. ${ }^{214}$

As this line of cases indicates, state and lower federal courts have used various methods of analysis to determine the constitutionality of local government prayer. The final Part of this Comment undertakes an independent analysis of this issue, focusing on school board prayer and using the Court's major Establishment Clause tests as the foundation for the analysis.

${ }^{210}$ Carter v. Broadlawns Med. Ctr., 857 F.2d 448, 453 (8th Cir. 1988).

2II See North Carolina Civil Liberties Union Legal Found. v. Constangy, 947 F.2d 1145, 1147-49 (4th Cir. 1991) (rejecting Marsh and applying the Lemon test), cert. denied, 505 U.S. 1219 (1992). The court affirmed the district court's finding that the judicial prayer violated all three prongs of Lemon and found that the prayer had an "intrinsically religious" purpose, see id. at 1150 , and that the nature of the prayer as part of an official government proceeding violated both the effects and entanglement prongs of Lemon. See id. at 1150-52.

212 Id. at 1148; cf. Warner v. Orange County Dep't of Probation, 95 F.3d 202, 213 (2d Cir. 1996) (rejecting application of Marsh to a challenge to religiously oriented alcohol rehabilitation program because Marsh "relied heavily on the long tradition of public prayer in th [e] context" of state legislatures).

213 Constangy, 947 F.2d at 1149.

214 See Society of Separationists, Inc. v. Whitehead, 870 P.2d 916 (Utah 1993). This case presented at least two facts which contrast with most other municipal prayer cases. First, the "invocations" in question were offered by "a wide variety of community organizations, churches and individuals," rather than simply local clergy or elected officials. Id. at $918 \mathrm{n} .2$. Second, the city council "invited the presentation of thoughts, readings and invocations," as opposed to simply prayers. Id. The court, after discussing the long history of oppression of Utah's religious majority, which led to the enactment of the religion clauses of the state constitution, see id. at 921-29, noted that there was no indication "the City Council favored particular religions or religion in general in scheduling participants" for its invocations, see id. at 939 (emphasis added); $c f$. Lee v. Weisman, 505 U.S. 577, 630 n.8 (1992) (Souter, J., concurring) ("If the State had chosen its graduation day speakers according to wholly secular criteria, and if one of those speakers (not a state actor) had individually chosen to deliver a religious message, it would have been harder to attribute an endorsement of religion to the State."). 


\section{Establishment ClAUSE Tests}

As noted, the Court's major Establishment Clause test for the past quarter-century has been the so-called Lemon test. Below I will examine school board prayer under this test, as well as under the "endorsement" test which Justice O'Connor has advocated as a recapitulation of Lemon, and under the "coercion" analysis which Justices Kennedy and Scalia have advocated, in slightly different forms. I will conclude by examining two arguments sometimes put forth by government prayer proponents: that government prayer is constitutional as simply a permissible expression of "civic religion" or that such prayer is compelled, when desired by citizens or elected officials, by the Free Speech Clause of the First Amendment.

\section{A. The Lemon Test}

The Lemon test ${ }^{215}$ has been around for a quarter of a century and criticism of the test for almost as long. ${ }^{216}$ I will assume, for the purpose of analyzing school board prayer, that the test is both a valid means of evaluating Establishment Clause challenges and still a living organism, if perhaps only on life support. ${ }^{217}$ The test requires that a government action meet three "prongs": first, that the action have a secular purpose; second, that the primary effect of the action not be to advance or inhibit religion (or a particular religion); and third, that the action not

215 See Lemon v. Kurtzman, 403 U.S. 602, 612-13 (1971).

216 Although some courts and commentators have pronounced the death of Lemon, this may simply be wishful thinking on the part of those who believe the test is too difficult a hurdle for the state when it acts in the field of religion. Criticism of Lemon, however, serves the purpose of permitting lower courts to ignore its framework in favor of whatever test they feel is most appropriate. See, e.g., Chaudhuri v. Tennessee, 886 F. Supp. 1374, 1383-87 (M.D. Tenn. 1995) (arguing that the Court in Lee "abandoned the traditional test" from Lemon in favor of a coercion test and then proceeding to adopt Justice Scalia's dissenting opinion from Lee and the trial court's own reading of constitutional history as the basis for rejecting a challenge to sectarian graduation prayer).

${ }^{217}$ In a post-Lee decision, Justice Blackmun defended the use of Lemon and pointed out the continued validity of its underlying principles:

I write ... to note my disagreement with any suggestion that today's decision signals a departure from the principles described in Lemon v. Kurtzman. The opinion of the Court ... relies upon several decisions ... that explicitly rested on the criteria set forth in Lemon. Indeed, the two principles on which the opinion bases its conclusion that the legislative Act is constitutionally invalid essentially are the second and third Lemon criteria.

Board of Educ. of Kiryas Joel Village Sch. Dist. v. Grumet, 512 U.S. 687, 710 (1994) (Blackmun, J., concurring) (citations omitted). 
create an excessive entanglement between government and religion. The first two prongs actually date at least as far back as 1963 and Schemp $p{ }^{218}$ while the entanglement prong was explicitly outlined in the 1970 Walz decision. ${ }^{219}$

\section{Purpose Prong}

Because the Lemon test requires only that a government action have a secular purpose (and not primarily a secular purpose), the first prong is not normally a very difficult test to meet. However, with government religious activity in the public school context, problems have often arisen in the purpose arena. ${ }^{220}$ In the cases that have applied Lemon to government-sponsored prayer, the only purpose put forth has been, in one form or another, "to solemnify governmental proceedings." ${ }^{\text {22l }} \mathrm{Al}$ though analysis of whether prayer can ever be anything other than an explicitly religious activity will be deferred until later, ${ }^{222}$ it is highly questionable whether the purpose of prayer at school board meetings is to create a solemn atmosphere. ${ }^{223}$ First, unlike legislative or congressional

218 See School Dist. of Abington Township v. Schempp, 374 U.S. 203, 222 (1963) ("[T]o withstand the strictures of the Establishment Clause there must be a secular legislative purpose and a primary effect that neither advances nor inhibits religion." (citations omitted)).

${ }^{219}$ See Walz v. Tax Comm'n of New York, 397 U.S. 664, 674 (1970) ("We must also be sure that the end result-the effect-is not an excessive government entanglement with religion."). Justice Jackson expressed similar sentiments in a dissenting opinion more than two decades earlier, noting that the First Amendment religion clauses were 'intended not only to keep the states' hands out of religion, but to keep religion's hands off the state, and, above all, to keep bitter religious controversy out of public life." Everson v. Board of Educ., 330 U.S. 1, 26-27 (1947) (Jackson, J., dissenting).

${ }^{220}$ In fact, in each of the Court's "religion and public schools" cases from the late 1960 s through 1992, the purpose of the challenged government action was the key to the constitutional violation. See supra notes $68-86$ and accompanying text. This may be because, as one court put it in summarizing a number of these precedents, "controlling caselaw suggests that an act so intrinsically religious as prayer cannot meet, or at least would have difficulty meeting, the secular purpose prong of the Lemon test." North Carolina Civil Liberties Union Legal Found. v. Constangy, 947 F.2d 1145, 1150 (4th Cir. 1991).

${ }_{221}$ Marsa v. Wernik, 430 A.2d 888, 899 (N.J. 1981).

272 See infra note 259 and Part III.D.1.

${ }^{223}$ Although government officials who engage in religious activity will almost always aver an alleged secular purpose to inoculate their conduct from constitutional challenge, but cf. supra note 208, the courts should be "capable of distinguishing a sham secular purpose from a sincere one." Wallace v. Jaffree, 472 U.S. 38, 75 (1985) (O'Connor, J., concurring). This is easier in some cases than in others. For example, in Jager v. Douglas County School District, the practice of offering prayers prior to high school football games was challenged. See Jager v. Douglas County Sch. Dist., 862 F.2d 824 (11th Cir.), cert. denied, 490 U.S. 1090 (1989). The school district offered as an ex- 
prayer, ${ }^{224}$ invocations at public school board meetings appear to be a fairly new-and not yet widespread-innovation. ${ }^{225}$ Given this reality, one must ask what difference exists between the many school boards that continue to function without "solemnizing" their meetings and those that have found the recent need to do so.

Although lacking the factual record of a trial, it is possible to surmise the purpose behind the introduction of school board prayer in many of the situations in which the practice has been reported. These accounts consistently indicate an effort to return God to the schools. Whether intended as an example of proper religiosity for students, ${ }^{226}$ to prove government officials' allegiance to God (or even, in many circumstances, to a particular God), ${ }^{227}$ or simply to put the official impri-

pert witness a college football coach, who testified that "the invocation has a very strong positive, if you want to use the term 'secular,' that's certainly appropriate, effect on both the participants and the people in the stands." Hatcher, supra note 151, at 715 n.184. Despite this apparently coached testimony, the court found the prayers, which "frequently ma[de] reference to Jesus Christ, and often clos[ed] with the phrase 'in Jesus' name we pray," id. at 711, did not have a secular purpose, see Jager, 862 F.2d at 829-30.

In the context of school board meetings, the presumed purpose of creating a solemn atmosphere sometimes appears almost comical. See, e.g., Nancy Eshelman, Send Circus Away from E-Town, HARRISBURG PATRIOT, Oct. 17, 1996, at BI (reporting controversy and "circus" atmosphere surrounding passage of "pro-family resolution" by the school board, which opened its next meeting with a prayer "in the name of Jesus'"); Wendling, supra note 2 (reporting the board president's response to fellow board members who protested sectarian prayer: "this is the way it's going to be, so get used to it'").

${ }^{224}$ See Marsh v. Chambers, 463 U.S. 783, 786-90 \& n.11 (1983) (noting that legislative or congressional prayers are "deeply embedded in the history and tradition of this country").

${ }_{225}$ As noted earlier, it is difficult to determine precisely the prevalence of invocations at public school board meetings, see supra note 16 , and a thorough survey of the practice is beyond the scope of this Comment. However, newspaper accounts of the controversy surrounding the practice appear to confirm that the practice is neither historically longstanding nor extremely widespread. See sources cited supra note 16. On the other hand, opening a substantial number, if not a majority, of public school board meetings with prayer on a regular (usually monthly or biweekly) basis cannot be dismissed as a trivial matter. Cf. Lee v. Weisman, 505 U.S. 577, 594 (1992) (noting that the prayers at issue occurred only once a year for no more than two minutes, but that "the intrusion is greater than the two minutes or so of time consumed for prayers like these").

${ }_{226}$ See, e.g., Nelson, supra note 16 (reporting school board members "voted against the change [away from prayer] because the board acts as a model for district students"); Dana Tofig, Enfield Board Considers Starting with a Prayer, HARTFORD COURANT, Jan. 30, 1997, at B1 (noting a school board member's assertion that opening school board meetings with prayer "might send a good message to students and parents").

${ }_{227}$ Cf. Marsh, 463 U.S. at 792 (asserting the purpose of legislative prayer as "invok[ing] Divine guidance on a public body"); Jager, 862 F.2d at 830 ("[T] he School 
matur of government support on a majority's religious beliefs, ${ }^{228}$ the overriding purpose is clearly religious. These purposes can be summed up in the words of the Reverend Christopher L. Rose, who suggested that the intent of government prayer is "to recognize the authority of God over every aspect of our work, but might... also be the selfsanctification of those who endure those often empty phrases." ${ }^{22 x}$ If the former is the case, a secular purpose is difficult to divine; if the latter, one must wonder whether the requirement of a secular purpose is met when government officials use religious means to achieve "selfsanctification." Finally, although the Court has not required that government action be narrowly tailored to meet its asserted secular purpose, it is difficult to discern a secular purpose in using a religious invocation rather than any opening statement intended to solemnize a public school event. ${ }^{230}$

Arguing that a petition to a supreme being at an official government meeting has a secular purpose is somewhat like arguing that the purpose of attending a sporting event is to improve the economy. In both cases, one chooses the action for obvious reasons (to engage publicly in religious activity or to be entertained), but rationalizes the action by asserting as its purpose an incidental and even questionable consequence of the action (e.g., solemnizing a government event or improving the economy). This faulty logic not only ignores the duty of the courts to distinguish "a sham secular purpose from a sincere one, ${ }^{231}$ but also effectively prejudges the next step in the Lemon analysis by raising the tangential (and dubious) result of a religiously motivated activ-

District wanted to have invocations that publicly express support for Protestant Christianity.").

${ }^{2}{ }_{2}$ See, e.g., Ernesto Portillo Jr., Trustees Put Prayer on Agenda in Vista, SAN DIEgo UNION-TRIB., Feb. 18, 1993, available in 1993 WL 7472692 (noting one trustee's assertion that "prayer and invoking 'God' is a recognition of 'a higher force that brings everyone together' and ... acknowledges the 'commonality" of the school district's residents).

${ }_{299}$ Pollack, supra note 188, at 173.

${ }^{230}$ Cf. NATIONAL SCH. PUB. RELATIONS ASS'N, supra note 22, at 42 (suggesting that school boards "have musical numbers and other student presentations at the opening of the meeting[, as it] never takes more than 5 or 10 minutes and can go a long way toward setting a positive mood for all that is to follow"). In this vein, it is worth noting that in many instances the introduction of an opening prayer at school board meetings has followed the election to the school board of community members affiliated with religious organizations. See, e.g., Greg Tasker, A Change in Direction, BALTIMORE SuN, July 30, 1995, at 1C (describing the change in Garrett County school board practices after the election of Christian conservatives to the board).

${ }^{231}$ Wallace v. Jaffree, 472 U.S. 38, 75 (1985) (O'Connor, J., concurring in judgment). 
ity to the status of "primary effect."

\section{Effect Prong}

The second prong in the Lemon analysis, like the first, often requires separating bald assertions of secularity from the real effects of government religious activity. In this case, however, the test is presumably tougher. Because the primary effect of a government activity must not be to "advance or inhibit religion," incidental effects, such as solemnizing an occasion, cannot save a government activity whose overriding effect is to advance religion. ${ }^{232}$ The problem here is that the primary effect of government conduct in this area is often "in the eye of the beholder." Somewhat ironically (or perhaps not), those who support government religious activities often view the primary effect in purely secular terms, while those who oppose such activities see religion inevitably (and unconstitutionally) advanced every time the powerful and authoritative voice of government speaks in a religious tenor. ${ }^{233}$

While some have criticized challenges to government-sponsored prayer as being based on nothing more than abstract and unmeasurable harm to the listener, ${ }^{234}$ the "primary effect" alleged by prayer supporters is usually just as abstract and unmeasurable. ${ }^{235}$ However, in the

2932 Although an argument can be made that government-sponsored prayer "inhibits" religion by usurping a primary role of religious institutions (i.e., seeking the guidance or assistance of a supreme being in the daily affairs of men and women), I will concentrate on the tendency of government religious activity to "advance" religion.

${ }^{233}$ Different members of the Court have also expressed conflicting views of the effect of government religious activity. Justice Harlan, for example, viewed the effect of religious conduct as "the State... utilizing the prestige, power, and influence of a public institution to bring religion into the lives of citizens." Walz v. Tax Comm'n of New York, 397 U.S. 664, 696 (1970) (separate opinion of Harlan, J.) (internal quotation omitted). In Justice Scalia's opinion, the primary effect of a governmentsponsored prayer, offered by a sectarian religious leader, is to "inoculat [e persons of other faiths] from religious bigotry and prejudice in a manner that cannot be replicated" and "to foster among religious believers of various faiths a toleration-no, an affection-for one another." Lee v. Weisman, 505 U.S. 577, 646 (1992) (Scalia, J., dissenting).

${ }^{234}$ See, e.g., Lee, 505 U.S. at $637-38$ (Scalia, J., dissenting) (labeling as "ludicrous" and "beyond the absurd" the notion that students were coerced into participating in their graduation invocation and benediction).

${ }_{235}$ See, e.g., id. at 646 (Scalia, J., dissenting) (listing as benefits of prayer the fostering of toleration and affection). In addition, many government-prayer supporters assert that the absence of prayer has a detrimental effect on prayer supporters that is at least as abstract and "psychological" as any harm asserted by prayer opponents. See, e.g., E. Gregory Wallace, When Government Speaks Religiously, 21 FLA. ST. U. L. REV. 1183, 1197 (1994) (arguing that " $[w]$ hen the state uses secular language to convey ideas, 
context of public school board meetings, it is difficult to discern a primary effect other than the advancement of religion. Given public school boards' narrow scope of authority and important representative role within local communities, their explicitly religious conduct, visible to so many in the community and so clearly outside of their normal pedagogical or fiscal roles, ${ }^{236}$ is very likely to have the effect of advancing religion-and often a particular religion. In addition, given the role of public schools in the transmission of values to children, it is inevitable that pupils will get the message that religion is favored when their school board members officially declare, through prayer, their support for religion at the beginning of regular board meetings. ${ }^{237} \mathrm{Al}-$ though some prayer supporters may occasionally admit that this is the hoped-for effect of meeting prayers, ${ }^{238}$ it is an effect that the First Amendment leaves to religious, and not government, institutions. ${ }^{239}$

\section{Entanglement Prong}

Public school boards are in many cases the governmental bodies most responsive to local communities. ${ }^{240}$ Meetings of these boards are intended to be participatory affairs where important decisions regarding children and taxes are made. ${ }^{241}$ Given this reality, the very notion of injecting a religious activity into this democratic, pluralistic mix is problematic. Of greater concern, however, is the entanglement which inevi-

values, or perceptions of reality that are plainly at odds with deeply held religious beliefs, the effect on impressionable children can be significant").

${ }^{250}$ Cf. Sonia Nazario, Schools Defend Decision Against Offering Breakfast, L.A. TIMES, Nov. 20, 1994, at A38 (reporting that the school district declined to participate in a school breakfast program because "' $[s]$ chools need to educate," yet "the school board begins its meetings with Christian prayer").

${ }^{237}$ See, e.g., John Przybys, School Prayer, LAS VEGaS REV.J., Mar. 7, 1995, at IC (reporting a former school board member's observation that " "ii]t seems to me if it's deemed proper to open up the school board trustees meetings with prayer, that at least implies a belief that we believe prayer is important as it relates to education. Why shouldn't it be in schools?'"); see also sources cited supra notes 110-11.

${ }^{238}$ See supra note 110.

${ }^{239}$ More than two centuries ago, James Madison made the point that advancement of religion should be left (and was accomplished most successfully when left) to religious institutions. See JAMES MADISON, MEMORIAL AND REMONSTRANCE AGAINST RELIGIOUS ASSESSMENTS I 6 (1785), reprinted in 8 THE PAPERS OFJAMES MADISON 298, 301 (Robert A. Rutland et al. eds., 1973); $c f$. Mike Padgett, Status of School Prayer in Limbo, ARIZ. REPUBLIC, July 21, 1995, at 8 (reporting the school board president's statement that " ' $[w]$ e have a deal with churches-they don't teach algebra and we don't organize prayer" $"$ ).

${ }^{240}$ See supra Part I.B.1.

${ }^{241}$ See supra Part I.B.2. 
tably arises when such injection of religion is carried out in practice. Disputes arise over the general appropriateness of commingling religion and public education, perhaps one of the most volatile subjects in many communities. ${ }^{242}$ More specifically, prayers may be explicitly sectarian, creating even greater divisiveness within communities, ${ }^{243}$ orassuming only "nonsectarian" prayers may be used-elected officials and judges will find themselves in the business of vetting prayers, a practice the Court has consistently rejected, from Engel to Lee (and even in Marsh) ${ }^{244}$ Although the entanglement prong is perhaps the most criticized of the Lemon test's prongs, ${ }^{245}$ the Court's consistent rejection of any blending of religious activity and public schools supports the proposition that, in the context under consideration in this Comment,

${ }^{242}$ See, e.g., Ernesto Portillo Jr., School Trustees in Vista Pray, Then Set Policy on Invocations, SAN DIEGo UNION-TRIB., Mar. 12, 1993, at B2 (noting that a three-to-two vote to introduce prayer at board meetings "unleash [ed] a storm of controversy over the role of prayer in the public arena and during school-related functions"); Jeff Webb, Moment of Silence May Be Only Fair Option to Prayer, ST. PeTERSBuRg TiMes, Oct. 24, 1993, at 2 (anticipating an "emotionally charged and potentially divisive" dispute over prayer at board meetings, as well as some residents' insistence that board prayers be explicitly Christian); see also Strossen, supra note 156, at 610-15 (noting extreme volatility of school prayer issue). In many instances disputes erupt even among the (relatively few) members of the school board itself. See, e.g., Wendling, supra note 2, at 4B (reporting on a lawsuit by two school board members against the board president to enjoin his continued use of prayer to open meetings).

${ }_{249}$ See, e.g., Ernesto Portillo, Vista's Prayer Policy Is in Need of Guidance, SAN DIEGo UNION-TRIB., Mar. 3, 1993, available in 1993 WL 7475024 (noting a disagreement between a Buddhist priest and a Christian minister over the use of "God" in any school board prayer, with the latter arguing that "a generic prayer would not be appropriate"); Patricia White, Board Says, "Let Us Pray", ST. PeterSburg Times, Nov. 18, 1993, at $I$ (reporting that a board member "expressed concern ... that the traditional invocation might be offensive to non-Christians because of frequent references to Jesus Christ," and that this "created an outcry in the community. Some argued that Christian traditions founded this country and should remain at the root of prayers at public meetings."). In Engel the Court noted that avoiding the political divisiveness which often accompanied government expression of particular religious beliefs was one of the specific aims of the Establishment Clause. See Engel v. Vitale, 370 U.S. 421, 429-30 (1962).

${ }^{244}$ See Lee v. Weisman, 505 U.S. 577, 587-88 (1992) (noting problems when a school chose the clergyman and controlled the content of the prayers given at graduation); Marsh v. Chambers, 463 U.S. 783, 795 (1983) (stating that "it is not for [the Court] to embark on a sensitive evaluation or to parse the content of a particular prayer"); Engel, 370 U.S. at 425 (stating that "it is no part of the business of government to compose official prayers"); $c f$. Snyder v. Murray City Corp., 902 F. Supp. 1444, 1450 (D. Utah 1995) (scrutinizing plaintiff's proposed "prayer" for opening city government meetings and rejecting it because the prayer was "not rooted in religion").

${ }_{245}^{24}$ See, e.g., Bowen v. Kendrick, 487 U.S. 589, 615-16 (1988) (Rehnquist, C.J.) (5-4 decision) (discussing problems with the entanglement prong and citing prior concurring and dissenting opinions criticizing this prong of Lemon). 
an entanglement is both inevitable and unconstitutional.

\section{B. The Endorsement Test}

Justice O'Connor has argued for greater flexibility in Establishment Clause jurisprudence than strict adherence to the Lemon test might allow. Her formulation, usually dubbed the "endorsement test," is very similar to the Lemon test and therefore will not be discussed at length. The endorsement test collapses Lemon into a single overriding analysis, which asks whether a government action has the effect, whether intentionally or unintentionally, of "communicating a message of government endorsement or disapproval of religion. ${ }^{246}$ Put another way, government action must not send "a message to nonadherents that they are outsiders, not full members of the political community, and an accompanying message to adherents that they are insiders, favored members of the political community. ${ }^{247}$ A key question in applying the test is who gets to determine the meaning of a government message. Should a court analyze whether prayers at school board meetings communicate a message of government endorsement of religion from the perspective of a long-time community member who adheres to the same faith as the members of the board? Or should it analyze the problem from the viewpoint of a newcomer to the community who happens to belong to a minority faith-or is nonreligious? In a recent case, Capitol Square Review E' Advisory Board v. Pinette, ${ }^{248}$ Justice O'Connor (joined by Justices Souter and Breyer) disagreed with Justice Stevens on the application of the test to a private religious display on government property. ${ }^{249}$ Their dispute revolved around whether an observer would perceive the message as being endorsed by government, not around what

${ }^{246}$ Lynch v. Donnelly, 465 U.S. 668, 692 (1984) (O'Connor, J., concurring).

${ }^{247}$ Id. at 688 (O'Connor, J., concurring); see also Wallace v. Jaffree, 472 U.S. 38, 70 (1985) (O'Connor, J., concurring in judgment) (stating that the endorsement test "preclude[s] government from conveying or attempting to convey a message that religion or a particular religious belief is favored or preferred").

248 115 S. Ct. 2440 (1995). Pinette involved a challenge to a local government's denial of an application from the Ku Klux Klan to erect a cross in a public square. See id. at $2444-45$.

249 Compare id. at 2452 (O'Connor, J., concurring) (using the test of "reasonable, informed observer"), with id. at 2466 \& $n .5$ (Stevens, J., dissenting) (using the test of "the universe of reasonable" observers, including one "who may not share the particular religious belief" expressed by the symbol or conduct at issue). Taking sides in this dispute is not the point of the present Comment-nor do I believe it necessary in order to analyze the issue under consideration. For further discussion of the "reasonable observer" aspect of the endorsement test, see Developments in the Law, supra note 158 , at $1648-50$. 
the observer would perceive as the message itself. Justice O'Connor did not rule out an endorsement violation where the message was not the government's, ${ }^{250}$ but she did not believe a "reasonable, informed observer" in this particular case would perceive the message as that of the government.

Turning to the situation of school board prayer, much of the discussion above regarding the Lemon test is applicable here. There would appear to be little doubt that a prayer given at the beginning of an official school board meeting is perceived as a message of the government. For one thing, the message is that of the government unless the prayer is made by a private person as part of an open public forum. ${ }^{251}$ For another, unlike the situation in Pinette, ${ }^{252}$ with school board prayer, government officials are actively engaging in religious activity, either directly through the giving of prayers, or indirectly by affirmatively arranging for other community members or district employees to give an invocation. ${ }^{253}$ The only question to be answered would be whether the message thus conveyed is one of endorsement of either religion in general or a particular religion. In the case of sectarian prayers, which the school board invocations often are, ${ }^{254}$ the answer would seem obvious. Even where less than explicitly sectarian prayers are given, it would be difficult to discern a message other than support for religion. The message of the prayer would appear unmistakable, even to the "reasonable, informed observer": the school board approves of the practice and has officially endorsed its inclusion in the board's proceedings despite the incongruity of a government entity authorized solely to raise funds and educate children engaging in religious practices.

${ }^{250}$ See Pinette, 115 S. Ct. at 2454 (O'Connor, J., concurring) (stating that a violation may exist if a religious group's message dominates a public forum).

${ }_{231}$ For a discussion of the questionable proposition that an invocation at a school board meeting would fall under the public forum doctrine, see infra Part III.D.2. Even in the unlikely event that the prayer was considered private speech within a public forum, Justice O'Connor (and Justices Souter and Breyer, who joined her opinion) would not rule out an endorsement test violation. See Pinette, 115 S. Ct. at 2454 (O'Connor, J., concurring) ("At some point, for example, a private religious group may so dominate a public forum that a formal policy of equal access is transformed into a demonstration of approval.").

${ }^{252}$ See supra notes $250-51$ and accompanying text.

253 See sources cited supra note 16.

254 See sources cited infra notes 282-83. Leaving aside for the moment the message of any prayer to "nonbelievers," in the many cases where the school board prayer is explicitly sectarian, there would seem to be little doubt that the invocations are sending "a message to nonadherents that they are outsiders, not full members of the political community." Lynch v. Donnelly, 465 U.S. 668, 688 (1984) (O'Connor, J., concurring). 
Although two years earlier she had joined the Court's opinion in Marsh, Justice O'Connor noted in Wallace that a "moment of silence law that is clearly drafted and implemented so as to permit prayer, meditation, and reflection within the prescribed period, without endorsing one altermative over the others, should pass" the endorsement test. ${ }^{25}$ This would seem to eliminate any prayers at school board meetings, while permitting "moments of silence" which solemnized board meetings and allowed community members and elected officials to "pray, meditate, or reflect" as they chose. Finally, the case of school board prayer "is not a case like Marsh $v$. Chambers in which government officials invoke spiritual inspiration entirely for their own benefit without directing any religious message at the citizens they lead. ${ }^{256}$ Unless the prayer is done prior to the meeting, outside the observation of the public, school boards are clearly "directing [a] religious message at the citizens they lead" and that religious message violates the endorsement test.

\section{The Coercion Test}

Although Justice Kennedy advocated a fairly narrow coercion-based analysis in one of his first Establishment Clause cases, ${ }^{257}$ more recently he split with the Court's other coercion proponents in Lee v. Weisman. ${ }^{258}$ Although a detailed analysis of the coercion test is beyond the scope of this Comment, ${ }^{259}$ for present purposes, it should be noted that the pri-

${ }^{255}$ Wallace v. Jaffree, 472 U.S. 38, 76 (1985) (O'Connor, J., concurring in judg. ment) (emphasis added). Justice $O^{\prime}$ Connor also noted in Wallace that the reasonable observer in the analysis should be one "acquainted with the text, legislative history, and implementation" of a challenged statute. Id. Although school board prayers are often implemented outside of the official policymaking process, the act itself of opening school board meetings with prayer is an official act which can be analyzed from the perspective of the reasonable observer. Cf. Pembaur v. City of Cincinnati, 475 U.S. 469,480 (1986) (noting that municipal liability for civil rights violations "may be imposed for a single decision by municipal policymakers under appropriate circumstances").

${ }_{256}$ Lee v. Weisman, 505 U.S. 577, 630 n.8 (1992) (Souter, J., concurring) (citation omitted).

${ }_{257}$ Justice Kennedy interpreted Court precedents, up to 1989 , as requiring only that the state not "give direct benefits to religion" to the extent that it establishes (or tends to establish) an official religion and that government "not coerce anyone to support or participate in any religion or its exercise." County of Allegheny v. ACLU, 492 U.S. 573, 659 (1989) (opinion of Kennedy, J.). He rejected analysis of the endorsement test through the eyes of "nonadherents," id. at 670 , expressing confidence that "communities [would] make reasonable judgments respecting the accommodation or acknowledgment" of different religious expressions, id. at 679 .

${ }_{258}^{238} 505$ U.S. 577 (1992). For a full discussion of Lee, see supra Part I.A.3.

${ }^{259}$ For a thorough discussion of the coercion test, see Steven G. Gey, Religious Coer- 
mary disagreement among the coercion proponents in Lee was over the definition of coercion. ${ }^{260}$ The majority held that attendance at one's (nonmandatory) graduation ceremony was "in a fair and real sense obligatory" because of the emotional and psychological pressures to attend. ${ }^{26 t}$ Therefore, it was as if the government had "coerced" a graduate to participate in whatever activities took place at the ceremony since attendance was not truly voluntary. In addition, the graduate was coerced to participate in the specific religious activities at the graduation from public and peer pressure to conform. ${ }^{262}$

The dissent found this analysis "incoherent," "ludicrous" and

cion and the Establishment Clause, 1994 U. ILL. L. REV. 463, $482-526$ (discussing problems with the coercion analysis and asking "whether any meaningful limits would remain on government activity advancing the majority's religious values" under the coercion test). It should be emphasized that, despite the discussion in the text of the coercion analysis, earlier Supreme Court cases explicitly stated that a constitutional violation under the Establishment Clause did not depend on a showing of coercion, whether defined broadly or narrowly. See supra notes 57-59 and accompanying text.

One problem with the narrow coercion test that is particularly relevant to school board prayer does deserve mention. In Lee, the dissent dismisses the majority's assertion that a silent protester has been coerced to "participate" in prayer as "nothing short of ludicrous." Lee, 505 U.S. at 637 (Scalia, J., dissenting). Although the dissent ridicules the notion that sitting (or even standing with those who wish to pray) somehow equals participation, its analysis demonstrates a complete failure to acknowledge the unique nature of prayer. Citing Bamette, the dissent notes that " $[t]$ he government can, of course, no more coerce political orthodoxy than religious orthodoxy." Id. at 638. However, sitting quietly while others recite the pledge of allegiance or enduring the barbs of a government speaker advocating political views antithetical to those of the listener have a fundamentally different effect than sitting, standing, or in any way being present as a prayer is recited. "Prayer is not a statement about something, it is a petition directed to someone.... To pray is not only to acknowledge a belief ... it is to practice a belief and to enter into it." Hall, supra note 6, at 59 (emphasis added). This difference is one of the reasons that "the Establishment Clause is a specific prohibition on forms of state intervention in religious affairs with no precise counterpart in the speech provisions." Lee, 505 U.S. at 591.

What is more, when a prayer is recited at a government function, by either a government official or one explicitly authorized to pray by a government official, a person exercising her legal right (and often community obligation) to be present at that government event is subjected to far more than "the minimal inconvenience of standing or even sitting in respectful nonparticipation." Id. at 646 (Scalia, J., dissenting); $c f$. Hall, supra note 6 , at 89 ("A state has no reason to force citizens with deeply held religious beliefs to witness in respectful silence religious rites they deem heretical. Government has no reason to ask that different religious faiths appreciate one another or that they participate together in joint religious exercises.").

${ }^{260}$ I will refer to the Lee majority's view as the "broad coercion" test and to the analysis employed by the Lee dissent as the "narrow coercion" test.

${ }^{261}$ Lee, 505 U.S. at 586.

${ }^{262}$ See id. at 593-94 (citing psychological studies as evidence that "adolescents are often susceptible to pressure from their peers towards conformity"). 
"beyond the absurd. ${ }^{263}$ In short, the dissenting Justices argued that a constitutional violation existed only where there was "coercion of religious orthodoxy... by force of law and threat of penalty," ernment religious activity was explicitly sectarian, in that it endorsed particular details regarding "a benevolent, omnipotent Creator and Ruler of the world ... (for example, the divinity of Christ). ${ }^{265}$

Under either of these versions of the coercion test, analysis of the practice of public school board prayer centers on two questions: what coercion is present and what is the nature of the prayer. Under the Lee majority's analysis, "subtle coercive pressures" to support or participate in the school board prayer would suffice to create a constitutional violation. $^{266}$ This analysis is similar to ideas expressed by concurring Justices in Engel ${ }^{267}$ and Schempp. ${ }^{268}$ The unifying theme in each of these conceptions of coercion is a rejection of any government-imposed tradeoff. ${ }^{269}$

${ }^{263}$ Id. at 636-38 (Scalia, J., dissenting).

${ }^{264} I d$. at 640 .

265 Id. at 641 . The latter part of the dissent's test, the requirement that government not endorse (even without coercion) explicitly sectarian religious messages, still appears to leave room for many government-sponsored prayers. The definition of sectarian, or "specifying details upon which men and women who believe in a benevolent, omnipotent Creator and Ruler of the world are known to differ (for example, the divinity of Christ)," id. (Scalia, J., dissenting), would seem to allow prayers as explicitly sectarian as the Lord's Prayer, as long as they did not mention "the divinity of Christ." But of. sources cited infra notes 280 and 284. This would allow for "nonsectarian" prayers which invoke God (or perhaps even Jesus, as long as his "divinity" is not mentioned) to the exclusion of nonbelievers and nontheists.

In addition, the dissent put forth an argument that the prayers in question in Lee were an "expression of gratitude to God that a majority of the community wishes to make," rather than an official government expression of sectarian religious beliefs. Lee, 505 U.S. at 646 (Scalia, J., dissenting). One critic interpreted this argument as an assertion that "true religious liberty can exist only if the government has the authority to keep pesky individual dissenters from interfering with the community's collective religious observances." Gey, supra note 259, at 524. The issue of whether governmentsponsored prayers can be interpreted as private "community" speech as opposed to public "government" speech is briefly discussed infra Part III.D.2.

266 Lee, 505 U.S. at 588.

267 Justice Douglas noted that "[f]ew adults, let alone children, would leave our courtroom or the Senate or the House while those prayers are being given. Every such audience is in a sense a 'captive' audience." Engel v. Vitale, 370 U.S. 421, 442 (1962) (Douglas, J., concurring).

${ }_{20}$ Justice Brennan declared that "the State could not constitutionally require a student to profess publicly his disbelief as the prerequisite to the exercise of his constitutional right of abstention." School Dist. of Abington Township v. Schempp, 374 U.S. 203, 289 (1963) (Brennan, J., concurring).

${ }^{269}$ As Justice Kennedy said in Lee, rejecting the notion that the religious objector must bend to the will of the majority, "[i]t is a tenet of the First Amendment that the State cannot require one of its citizens to forfeit his or her rights and benefits as the 
As with children wishing to attend their graduation, adults exercising their legal right to participate in the deliberations of their local government ${ }^{270}$ should not be forced to choose between participation in the activity or subjection to a religious exercise that offends their most fundamental belief system. ${ }^{271}$ Therefore, it appears likely that the broad coercion test advanced by the majority in Lee would strike down the practice of school board prayer.

Even under the Lee dissent's narrow coercion test, one can argue that being forced to abstain from participation in the workings of government (either as an elected official-when a board member objects to the religious practice-or as a community member) is a "coercion ... by force of law and threat of penalty."272 Given the Lee dissent's view, however, that silence in the face of a petition to a supreme being is simply "respectful nonparticipation," it is highly unlikely that the proponents of the narrow coercion test would find coercion, rather than an unwillingness to show "respect for the religious observances of others," if a prayer objector felt compelled to leave the meeting of a government body engaged in prayer. ${ }^{273}$ The nature of the prayer would seem the most likely method of striking down a school board prayer under the Lee dissent's narrow coercion test. This ensures that the practice of school board invocations would never be found facially unconstitutional, but rather individual occurrences of invocations which crossed the line into the explicitly "sectarian" might be successfully challenged,

price of resisting conformance to state-sponsored religious practice." Lee, 505 U.S. at 596.

${ }^{270}$ The Court has held that when a State gives its citizens the right to vote, it will be subjected to the strictest scrutiny in attempting to justify the classification and exclusion of certain groups of citizens from that right of electoral participation, including in the school district context. See Kramer v. Union Free Sch. Dist. No. 15, 395 U.S. 621,626 (1969).

271 Justice Blackmun's comments in Lee apply to this analysis of the "coercion" involved when one must choose between maintaining involvement in the affairs of one's local schools and refraining from participation in religious exercises to which one objects:

Democracy requires the nourishment of dialog and dissent, while religious faith puts its trust in an ultimate divine authority above all human deliberation. When the government appropriates religious truth, it "transforms rational debate into theological decree." Those who disagree no longer are questioning the policy judgment of the elected but the rules of a higher authority who is beyond reproach.

Lee, 505 U.S. at 607 (Blackmun, J., concurring) (citation omitted).

${ }^{272}$ Id. at 640 (Scalia, J., dissenting) (emphasis removed).

${ }^{273} I d$. at 638,646 . But see supra note 259 (criticizing the Lee dissent's conception of public prayer). 
if the prayers were sufficiently sectarian and if they were sufficiently connected to the official government body. ${ }^{274}$

\section{Alternative Arguments for School Board Prayer}

There are two final arguments put forth by proponents of government-sponsored prayer, which have features similar to the narrow coercion analysis. I will discuss each briefly below.

\section{Civic Prayer}

Supporters of civic prayer assert similar arguments to those of the dissent in $\mathrm{Lee}^{275}$ Civic prayer proponents insist on the right of "citizens ... to state their dependence on God in a way as to make it a simple and common prayer for all. ${ }^{276}$ As applied to school board prayer (or other government prayer), the civic prayer argument suffers from at least three fundamental flaws.

First, although the nonpreferentialist argument has been unequivocally rejected by the Court, ${ }^{277}$ the civic prayer argument presumes, as does the narrow coercion analysis, that it is permissible for government to endorse and participate in a religious activity that excludes nonbelievers. Prayer is, by definition, religious, and whether it is called "civic" or "secular" is irrelevant to this reality. ${ }^{278}$ Unless decades of Court precedents are overturned and the favoring of religion in general is allowed, even a generic religious exercise is not permissible.

Second, what is often called "civic prayer" is almost inevitably sectarian. Given the wide diversity of religions (and nonbelievers) in the United States $^{279}$ and the difficulty of finding (or writing) a prayer that addresses all beliefs, ${ }^{280}$ a truly "nonsectarian" prayer is almost impossible

${ }^{274}$ See supra note 265 and infra Part III.D.2.

${ }^{275}$ See discussion supra note 259; see, e.g., Wallace, supra note 235 , at 1264 \& n.380 (suggesting that " $[\mathrm{m}]$ erely listening to a prayer at an otherwise secular event carries no inherent religious significance" and should not comprise, even when taking place before a captive audience, a constitutional violation).

276 DONOVAN ET AL., supra note 149 , at 81.

277 See, e.g., School Dist. of Abington Township v. Schempp, 374 U.S. 203, 216-17 (1963).

${ }^{278}$ See supra note 259; see also 117 CONG. REC. 39,898 (1971) (statement of Rep. Drinan) ("The very concept of prayer seems inevitably to include a theistic element. It is precisely because of this element that any prayer must be deemed to reflect the theology of a particular group and is consequently denominational or sectarian."), quoted in AIIEY, supra note 135, at 174.

279 See supra note 166.

${ }^{280}$ See ALLEY, supra note 135, at 137 ("Jews do not have a Christian heritage, while 
to achieve.

Finally, it does not take much of a slippery slope for "civic prayer" to descend into explicitly sectarian prayer, given the inclinations of any majority to ratify its own beliefs ${ }^{281}$ and the evidence of serious ignorance by many elected officials regarding what exactly constitutes a sectarian prayer. ${ }^{282}$ Perhaps the best example of this latter problem is the fact that so many school boards that have invocations begin their meetings with the Lord's Prayer. ${ }^{283}$ When confronted by objectors, many of these officials entirely fail to understand how explicitly sectarian is this prayer. $^{284}$

\section{Free Speech}

The final argument, discussed only briefly because of its general implausibility in the specific context of public school board meetings, is the free speech argument. ${ }^{285}$ In order for a community resident (or

Christians most certainly do have a Jewish heritage. Therefore, Jewish citizens do not, in point of fact, have a Judeo-Christian tradition."); NORD, supra note 112, at 260-61 ("All prayers are formulated in the language and symbols of some religion rather than others. ... There is no such thing as nonsectarian religion; to pray is to take sides among religions."); Loconte, supra note 158, at 27-30 (noting that arguments for a common prayer are based on a "religious consensus" that "no longer exists").

${ }^{281}$ See, e.g., Fleet, supra note 178, at 561 (noting James Madison's objection that religious proclamations tend to narrow "to the standard of the predominant sect").

${ }_{282}$ See, e.g., Patricia White, The Children Shall Lead Them to Pray, Sr. PETERSBURG TIMES, Nov. 14, 1993, at 1 (discussing a local school board's debate about whether to include the name "Jesus Christ" in board prayers).

${ }^{285}$ See, e.g., Lori Badders, Board Boots Resident, YORK DAILY REC., Nov. 20, 1992, at 1C (describing how the audience at a school board meeting bowed their heads to recite the Lord's Prayer); Debbie Wygent, Octorara Board to Consider New Guidelines for Public Meetings, LANCASTER NEW ERA, Jan. 19, 1994, at B4 (noting that a local school board intended to retain the practice of reciting the Lord's Prayer).

${ }^{284}$ See, e.g., Nicholas AYO, THE LORD'S PRAYER: A SURVEY THEOlogical AND LITERARY 1, 6 (1992) (noting the centrality of the Lord's Prayer "to our daily Christian life" and that the "prayer is Jesus Christ as a living prayer, and the Christian in imitation of him"); see also PFEFFER, supra note 131, at 461 ("The courts that had held the Bible to be nonsectarian had no difficulty in so holding the Lord's Prayer.").

${ }^{285}$ This argument is still being played out in the context of graduation ceremonies in the wake of Lee. Some circuit courts have accepted the argument that a school board's delegation of the authority to pray (or to determine whether or not to pray) to nongovernment parties such as students, can constitutionalize the practice. See, e.g., Jones v. Clear Creek Indep. Sch. Dist., 977 F.2d 963, 970-71 (5th Cir. 1992). Other circuit courts have rejected this argument. See, e.g., ACLU v. Black Horse Pike Reg'l Bd. of Educ., 84 F.3d 1471, 1477-78 (3d Cir. 1996) (en banc). In prior cases, the Court appeared to reject unequivocally the argument that a school district could avoid Establishment Clause problems by "delegating" its authority to private parties. In Schempp, the Court said: 
elected official) to assert a free speech right to group prayer at an official public school board meeting, the location where the prayer is offered must be a "public forum., ${ }^{286}$ It is highly unlikely that an entire board meeting is a full-fledged "public forum," open to public comment at any time. ${ }^{287}$ At most, certain periods of the meeting may be designated a limited public forum, for the particular purposes deemed relevant by the school board. If, for example, a period is provided during the meeting for "public comments," the public can get up and "pray" for the board members or the district's students-if these are subjects within the range of "public comments" and if the speaker adheres to any reasonable restrictions that the board has placed on comments, such as time limits.

Three problems arise in trying to fit typical school board prayers into this limited public forum analysis. First, prayers almost always take

[W] cannot accept that the concept of neutrality, which does not permit a State to require a religious exercise even with the consent of the majority of those affected, collides with the majority's right to free exercise of religion.... [T] he Free Exercise Clause ... has never meant that a majority could use the machinery of the State to practice its beliefs.

School Dist. of Abington Township v. Schempp, 374 U.S. 203, 225-26 (1963).

${ }^{286}$ A full-length discussion of the Court's public forum doctrine is not necessary or possible here. The general rule, as outlined in Perry Education Ass' $n$ v. Perry Local Educators' Ass'n, 460 U.S. 37 (1983), usually places government property in one of three categories: 1) a public forum, in which any government restrictions on speech must be narrowly tailored to meet a compelling state interest; 2) a nonpublic forum, in which government restrictions on speech must only be reasonable and nondiscriminatory; and 3) a limited (or designated) public forum, which is created when the government chooses to open a nonpublic forum for particular types of speech. The government may restrict the limited public forum to certain subjects, but is otherwise constrained in its regulation of a limited public forum by the same rules that apply to a public forum. See id. at 45-46. It is the last category under which a portion of a government meeting would fall (that is, the government body has designated a part of its meeting as a limited public forum for any and all comments on particular subjects).

${ }^{287}$ Although school board meetings are often governed in part by state laws determining which portions must be open to the public and the extent to which the board must receive public comments, the meeting itself is not a constitutionally required public forum. "The Constitution does not grant to members of the public generally a right to be heard by public bodies making decisions of policy." Minnesota State Bd. for Community Colleges v. Knight, 465 U.S. 271, 283 (1984); see also City of Madison Joint Sch. Dist. No. 8 v. Wisconsin Employment Relations Comm'n, 429 U.S. 167,175 n.8 (1976) ("Plainly, public bodies may confine their meetings to specified subject matter and may hold nonpublic sessions to transact business.").

${ }^{288}$ See, e.g., Wygent, supra note 283 (noting that a school board, which opened its meeting with the Lord's Prayer, established a policy providing for public comment periods and clarifying that "meetings are not a public forum for debate or argument and that the board must be able to conduct its business in an orderly and reflective manner"). 
place at the opening moments of the meeting, during a time that is very much off-limits to members of the public. ${ }^{289}$ They do not regularly occur during a "public comments" period. ${ }^{200}$ Second, it is questionable whether most boards have the authority under their respective state laws to discuss, or to open their meetings for discussion of, religious matters, as opposed to issues related to the district's financial condition or the education of pupils. ${ }^{291}$ Finally, and most fundamentally, even if a school board actually has the power to deem a part of its meeting a "public forum" open for religious messages, any prayer must be allowed regardless of its content ${ }^{222}$-as long as it meets the noncontent-based criteria applicable to the forum. ${ }^{293}$

${ }^{289}$ Government bodies invariably refuse requests for "equal time" during opening prayers. See, e.g., Badders, supra note 283 (describing how a man was cited by police for disorderly conduct after he interrupted the recitation of the Lord's Prayer at a school board meeting); Santee to Consider $\$ 150$ Claim over Prayer Issue, SAN Diego UNION-TRIB., Sept. 28, 1988, at B3 (reporting that a member of the public filed a claim against the city for not allowing him to address the city council on the issue of its invocation).

${ }^{290}$ See sources cited supra note 16 (reporting method of giving prayer in various school districts).

פol See supra Part I.B.2.

${ }^{292}$ See City of Madison, 429 U.S. at 176 (holding that, where a public body opens its meetings to speakers on certain subjects, no speaker wishing to address that subject may be excluded on the basis of the content of his or her speech); see also Rosenberger v. Rector of the Univ. of Va., 115 S. Ct. 2510, 2517 (1995) (noting that the government may not exclude speech from an open forum it has created based on discriminatory criteria or distinctions "not 'reasonable in light of the purpose served by the forum'" (quoting Cornelius v. NAACP Legal Defense \& Educ. Fund, Inc., 473 U.S. 788, 806 (1985))). In short, even if the school board could create a forum for religious messages, but see infra note 293 , it could not exclude any religious messages from that forum based on the particular religious viewpoint of the message. Once a local minister is permitted to give the Lord's Prayer, the board must allow a Jewish prayer, Buddhist and Muslim religious messages, perhaps a Satanist chant, and any other "religious" messages offered during the designated time.

${ }^{293}$ For a discussion of the obvious problems this requirement will create, as board members attempt to discern which messages are appropriate for the religious forum they have opened, see supra Part III.A.3. This discussion also assumes, for the sake of analyzing the free speech argument, that it would be constitutionally permissible (as well as within its statutory authority) for a school board to create a limited public forum open only to religious messages. But of. Widmar v. Vincent, 454 U.S. 263, 275 (1981) (holding that a university could not exclude religious groups from its open forum for student groups, but implying that "empirical evidence that religious groups will dominate [the] open forum" might create an Establishment Clause concern). Justice Souter made a related point in his $L e e$ concurrence, noting that "[i]f the State had chosen its graduation day speakers according to wholly secular criteria, and if one of those speakers (not a state actor) had individually chosen to deliver a religious message, it would have been harder to attribute an endorsement of religion to the State." Lee v. Weisman, 505 U.S. 577, 630 n.8 (1992) (Souter, J., concurring) (emphasis 


\section{CONCLUSION}

"Counting votes" on the Supreme Court can be unseemly-and one engages in the practice at one's peril. ${ }^{294}$ Nevertheless, under the traditional "neutrality" principles of Lemon, to which Justice Stevens still adheres, ${ }^{205}$ under the endorsement test that Justices O'Connor, Souter and Breyer used in Pinette, and probably even under the broad coercion analysis that Justice Kennedy adopted in Lee, school board prayer would appear unconstitutional. This conclusion is consistent with the Court's holdings regarding graduation prayer and every other intrusion of religious activity into the public-school context. On the other hand, the narrow coercion analysis of Justices Scalia and Thomas and Chief Justice Rehnquist would almost certainly sanction any school board invocation, with the possible exception of one uttered officially by a board member and invoking the "divinity of Christ."

Were the Court to come to the conclusion that prayer at a public school board meeting is unconstitutional, it would be adhering to a half-century of consistent jurisprudence in the area of religion and public schools. It could reach this conclusion without overruling the narrow holding of Marsh and without revisiting that case's questionable reasoning. By doing so, the Court would go far toward maintaining both the modern, pluralistic public schools on which our nation depends and our religious institutions that will continue to thrive with educated and uncoerced adherents. Finally, such a decision would ensure that, "in matters of Religion, no man's right is abridged by the institution of Civil Society and that Religion is wholly exempt from its cognizance."296

added); $c f$. Board of Educ. of Kiryas Joel Village Sch. Dist. v. Grumet, 512 U.S. 687, 698 (1994) ("[A] State may not delegate its civic authority to a group chosen according to a religious criterion.").

${ }_{299}$ See, e.g., Serra, supra note 8 , at $797-98$ (predicting, prior to Lee $v$. Weisman, that Justices $O^{\prime}$ Connor and Kennedy would help form a majority for approving graduation prayer).

${ }^{293}$ Justice Ginsburg's short dissent in Pinette appears to indicate adherence to the traditional neutrality principles of Lemon. See Capitol Square Review \& Advisory Bd. v. Pinette, 115 S. Ct. 2440, 2475 (1995) (Ginsburg, J., dissenting) (citing Everson and suggesting that "the aim of the Establishment Clause is genuinely to uncouple government from church").

${ }^{296}$ MADISON, supra note 239, I 1, at 299 (emphasis added). 
